\title{
Velocity structure of upper ocean crust at Ocean Drilling Program Site 1256
}

\section{Stephen Swift}

Department of Geology and Geophysics, Woods Hole Oceanographic Institution, Mail Stop 24, Woods Hole, Massachusetts 02543, USA (sswift@whoi.edu)

\section{Marc Reichow}

Department of Geology, University of Leicester, Leicester LE1 7RH, UK (mkr6@leicester.ac.uk)

\section{Anahita Tikku}

ExxonMobil Upstream Research Company, Houston, Texas 77252, USA (anabita.a.tikku@exxonmobil.com)

\section{Masako Tominaga}

Department of Oceanography, Texas A\&M University, College Station, Texas 77843, USA

(masako.tominaga@gmail.com)

\section{Lisa Gilbert}

Maritime Studies Program of Williams College and Mystic Seaport, Mystic, Connecticut 06355, USA

(lgilbert@rwilliams.edu)

[1] We examine shipboard physical property measurements, wireline logs, and vertical seismic profiles (VSP) from Ocean Drilling Program/Integrated Ocean Drilling Program Hole 1256D in 15 Ma ocean crust formed at superfast spreading rates to investigate lateral and vertical variations in compressional velocity. In general, velocities from all methods agree. Porosity is inversely related to velocity in both the logging and laboratory data. We infer that microfracturing during drilling is minor in the upper $1 \mathrm{~km}$ of basement, probably due to connected pores and, thus, low effective stress. The closure of porosity to very low values coincides with the depth below which laboratory velocities diverge from logging velocities. We infer that porosity controls velocity in layer 2, lithostatic pressure controls the thickness of seismic layer 2, and the distribution of flow types determines seismic velocity in the upper $200 \mathrm{~m}$ of basement. In the sheeted dikes, changes in physical properties, mineralogy, and chemistry define clusters of dikes.

Components: 11,976 words, 16 figures.

Keywords: upper ocean crust; seismic structure; Integrated Ocean Drilling Program; D/V JOIDES Resolution; Expedition 309/312; Site 1256.

Index Terms: 7220 Seismology: Oceanic crust; 3036 Marine Geology and Geophysics: Ocean drilling; 0915 Exploration Geophysics: Downhole methods.

Received 9 July 2007; Revised 25 July 2008; Accepted 21 August 2008; Published 16 October 2008. 
Swift, S., M. Reichow, A. Tikku, M. Tominaga, and L. Gilbert (2008), Velocity structure of upper ocean crust at Ocean Drilling Program Site 1256, Geochem. Geophys. Geosyst., 9, Q10O13, doi:10.1029/2008GC002188.

Theme: Formation and Evolution of Oceanic Crust Formed at Fast Spreading Rates Guest Editors: D. A. H. Teagle and D. Wilson

\section{Introduction}

[2] During Leg 206, Ocean Drilling Program (ODP) initiated drilling at Site 1256 in the Guatemala Basin in order to reach plutonic rocks, which had eluded drilling at Hole 504B (Figure 1) [Alt et al., 1996; Wilson et al., 2003a]. On the basis of the variation with spreading rate in depth to the axial melt reflector observed in multichannel seismic profiles, Wilson et al. [2003a] predicted that crust formed at high spreading rates would have thinner extrusive and intrusive basalt, which could be more easily penetrated by available ocean drilling technology. Drilling resumed during Integrated Ocean Drilling Program (IODP) Expedition 309 and reached gabbros during Expedition 312 [Wilson et al., 2006]. One objective of drilling Hole 1256D was to determine the geologic basis for vertical changes in geophysical structure including the in situ seismic properties of upper ocean crust. The two distinguishing features of seismic velocity in seismic layer 2 are high lateral variability and a rapid increase $(1-2 \mathrm{~km} / \mathrm{s}$ per $\mathrm{km})$ with depth [Raitt, 1963; Helmberger and Morris, 1969; Houtz and Ewing, 1976; Orcutt et al., 1976; Whitmarsh, 1978; White, 1979; Spudich and Orcutt, 1980; Stephen, 1988]. This paper compares the results of shipboard velocity measurements at a wide range of scales with physical properties of recovered rocks to investigate the origin of these features.

\section{Regional Setting}

[3] The crust at Hole 1256D was created at15 Ma on the East Pacific Rise at a full spreading rate of 200-220 mm/a (Figure 1) [Wilson, 1996]. A site survey revealed no nearby disruptions to the linearity of magnetic anomalies and no seismic indications of shallow faulting [Wilson et al., 2003a, 2003b; Hallenborg et al., 2003]. Water depth $(3645 \mathrm{~m})$ and sediment thickness $(250 \mathrm{~m})$ are similar to that at Hole 504B (3460 m water and $275 \mathrm{~m}$ sediment), where crust was formed 6.6 Ma ago at $98 \mathrm{~mm} / \mathrm{a}$ full spreading rate [Swift et al., 1998b]. Seafloor and basement topography changes
$<50 \mathrm{~m}$ over $10 \mathrm{~km}$ [Shipboard Scientific Party, 2003b; Wilson et al., 2003b]. Basement depth is near that predicted from plate cooling models [Wilson et al., 2003a]. The nearest seamount that could have served as a hydrothermal up-flow zone is $15 \mathrm{~km}$ to the northeast, but small, sedimentcovered basement highs occur at $10 \mathrm{~km}$ range.

[4] The site survey obtained refraction profiles using ocean bottom hydrophones and a 20-air gun array shot at 130-180 m intervals [Wilson et al., 2003b; Hallenborg et al., 2003]. Inversion of a profile shot parallel to magnetic anomalies to a receiver located at Site 1256 gives a velocity solution for the upper crust that is very similar to velocity profiles collected determined from refraction experiments at Hole 504B ("NE" profile in Figure 16 in the work of Shipboard Scientific Party [2003a]; A. Harding, personal communication, 2008). Velocity increases at $1.3 \mathrm{~km} / \mathrm{s}$ per $\mathrm{km}$ from $4.8 \mathrm{~km} / \mathrm{s}$ at the basement surface. The vertical velocity gradient decreases to $0.2 \mathrm{~km} / \mathrm{s}$ per $\mathrm{km}$ at about $1500 \mathrm{~m}$ below seafloor (mbsf), marking the seismic layer $2 / 3$ boundary. Crustal thickness is $5-$ $5.5 \mathrm{~km}$.

\section{Methods}

\subsection{Physical Properties Measurements}

[5] We measured compressional velocities in the D/V JOIDES Resolution physical properties laboratory on seawater-saturated minicubes $\left(8-9 \mathrm{~cm}^{3}\right)$ cut from recovered rock cores. Sampling is biased because intervals with poor recovery are underrepresented and most samples were chosen for their homogeneity to avoid obvious cracks and vein material. Velocity measurements were made at laboratory pressure and temperature using the Ocean Drilling Program PWS3 velocity contact probe system with sound pulsed at $500 \mathrm{kHz}$ [Blum, 1997]. Repeat measurements were within $\sim 40 \mathrm{~m} / \mathrm{s}$ or $\sim 1 \%$ [Expedition 309/312 Scientists, 2006]. For Hole $1256 \mathrm{D}$, there is no systematic difference between laboratory velocities measured in vertical and horizontal directions. Velocities of diabase 


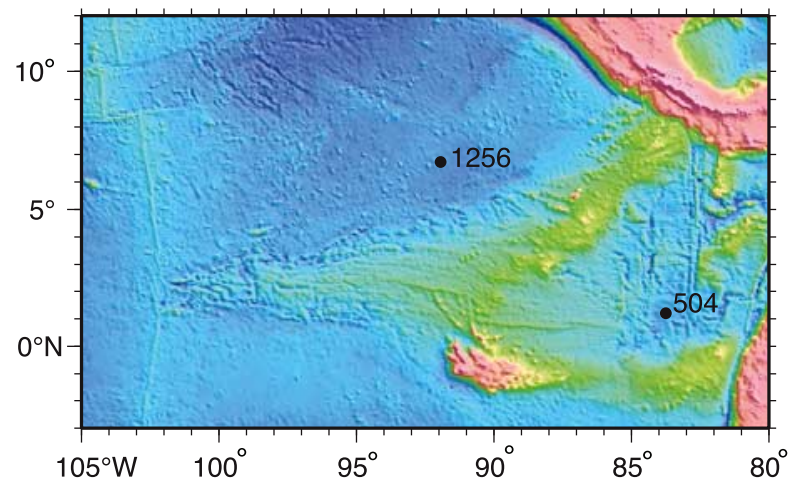

Figure 1. Ocean Drilling Program (ODP) Hole 1256D is located in the Guatemala Basin on 15 Ma crust that spread at $\sim 220 \mathrm{~mm} / \mathrm{a}$ (full rate). DSDP Hole 504B, the deepest penetration into igneous crust, is located in the Panama basin on $6.6 \mathrm{Ma}$ crust that spread at $\sim 95 \mathrm{~mm} / \mathrm{a}$ [Swift et al., 1998b].

made at the beginning of Expedition 312 were $\sim 0.6 \mathrm{~km} / \mathrm{s}$ lower than the deepest velocities measured on similar rocks at the end of Expedition 309 despite calibration of the instrumentation to known standards at the beginning of both expeditions. To resolve whether this was a calibration problem, six samples collected during Expedition 309 were rehydrated and remeasured during Expedition 312 giving an average offset of $0.42 \mathrm{~km} / \mathrm{s}$ (explanatory notes in the work of Expedition 309/312 Scientists [2006]). To test whether drying and hydration had altered the results, velocities of five Expedition 312 samples were rehydrated and remeasured postcruise after the PWS3 velocity system had been transported to Bremen, Germany. These velocities were not significantly different than the results obtained during Expedition 312, so we infer that there is a calibration offset between the velocities measured on Expeditions 309 and 312. Postcruise measurements at laboratory pressure confirm this conclusion [Tikku et al., 2006]. Velocities from both expeditions archived at IODP remain unchanged, but the Expedition 312 velocities reported in this paper are increased by $0.42 \mathrm{~km} / \mathrm{s}$ to correct for the calibration problem.

[6] Density and porosity are derived from wet and dry mass measured aboard the D/V JOIDES Resolution with Scientech 202 balances and volume measured by gas displacement with a Quantachrome Pentapycnometer [Blum, 1997]. Repeat measurements indicate an uncertainty in density of $0.03 \mathrm{~g} / \mathrm{cm}^{3}$ ( 1\%). Magnetic susceptibility was measured using a Bartington MS2 $\mathrm{m}$ coupled to a MS2C sensor coil with a diameter of $8.8 \mathrm{~cm}$ operating at $565 \mathrm{~Hz}$. The measurement resolution of the MS2C sensor is $4 \mathrm{~cm}$. Magnetic susceptibility measurements were carried out at $2.5 \mathrm{~cm}$ intervals on whole-core sections prior to splitting. Magnetic susceptibility measurements made during Expeditions 309 and 312 on core pieces $<8 \mathrm{~cm}$ in length are removed to reduce error due to edge effects. Precision is $2 \times 10^{-6} \mathrm{SI}$ units, and Bartington reports an accuracy of 5\% [Blum, 1997].

\subsection{Wireline Logs}

[7] Velocities of compressional, shear, and Stoneley waves were measured at $1-14 \mathrm{kHz}$ using the Schlumberger dipole sonic imager [Becker et al., 1998]. Transmitters and receivers are spaced 2.7$3.5 \mathrm{~m}$ apart. The data are high quality over most of the hole. Below 1300 mbsf, however, differences between sensors are large (rarely $<1 \mathrm{~km} / \mathrm{s}$ ), and values from the same sensor on different passes of the tool through the borehole differ by $>1 \mathrm{~km} / \mathrm{s}$. Weak arrivals and noisy sonic logging waveforms required careful reprocessing to obtain reliable compressional and shear velocities (G. Guerin et al., Velocity and attenuation in young oceanic crust: New downhole log results from DSDP/ ODP/IODP Holes 504B and 1256D, submitted to Geochemistry, Geophysics, Geosystems, 2008). Stoneley wave velocities have not been reprocessed and are unreliable below 1275 mbsf. Porosity was measured with the Schlumberger neutron Accelerator Porosity Sonde (APS), which records the energy decay of neutrons emitted from an electronic source. The uncorrected APS measurements used in this paper are biased to higher values in some intervals by the presence of alteration minerals, which also capture neutrons. Resistivity at two different depths into the borehole wall was measured with the Schlumberger Dual Laterolog. In the dikes, resistivity from the shallow and deep penetrating sensors diverge downhole as they do in Hole 504B, presumably due to increasing proportion of vertical fractures creating an anisotropic porosity distribution [Shipboard Scientific Party, 1988; Pezard and Anderson, 1989]. In intervals below $1373 \mathrm{mbsf}$, resistivity values from the deep sensor are clipped at 40,000 ohm meters, the maximum reading for the tool. Following investigations at Hole 504B, we use Archie's law to compute porosity from resistivity assuming constants "a" and "m" are 1 and 2, respectively [Becker et al., 1982; Pezard, 1990]. We computed pore fluid resistivity following Becker et al. [1982] using in situ temperature estimated from two linear equations fit to the temperature log recorded at 

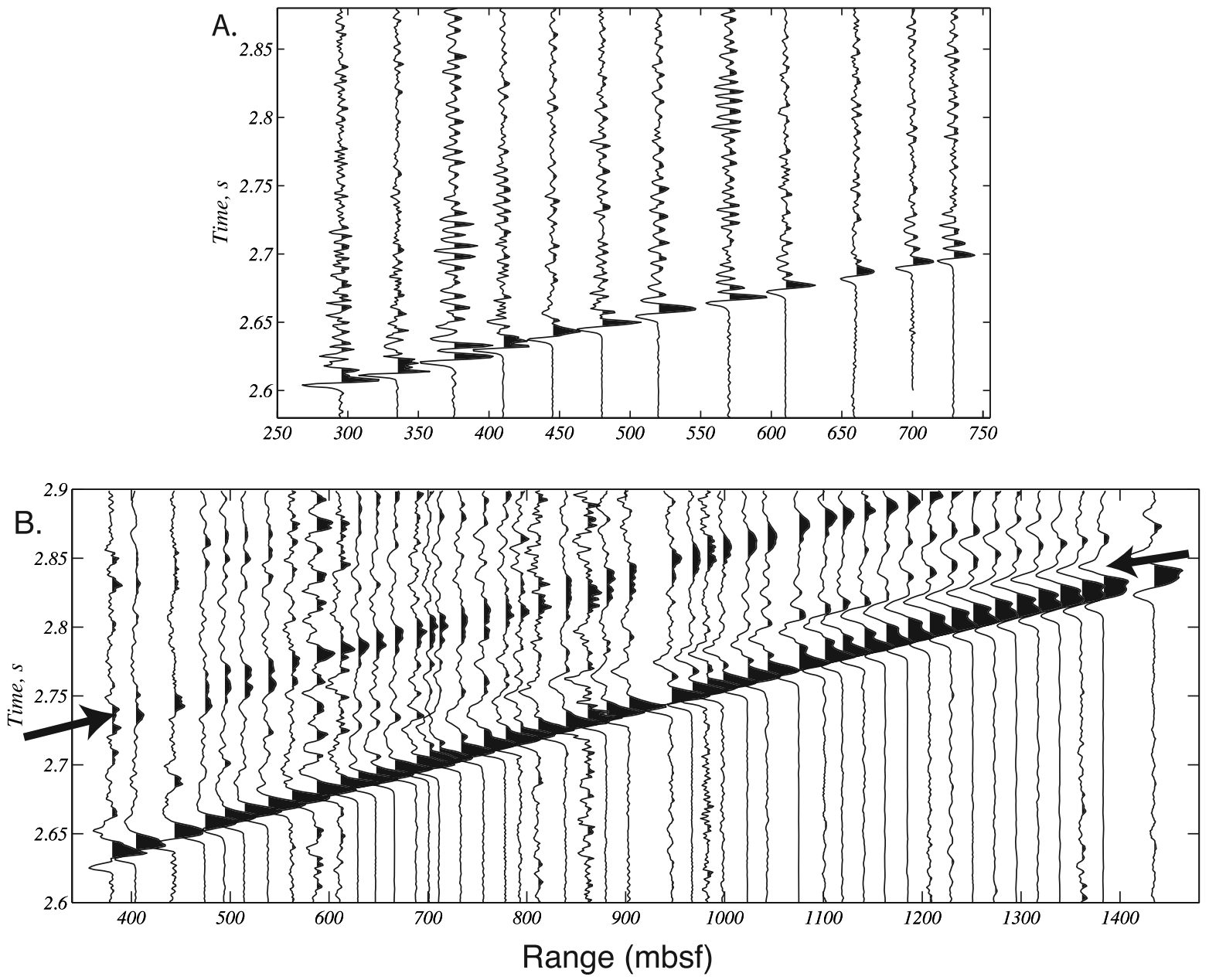

Figure 2. Record section of stacked VSP seismograms recorded on (a) Leg 206 and (b) Expedition 312. The amplitude of each seismogram is scaled so that all peak amplitudes are the same. In the Leg 206 seismograms, note the absence of a bubble pulse and the ringing in the coda due to seismometer resonance at $100-150 \mathrm{~Hz}$. In the Expedition 312 section, note the bubble pulse that follows the first arrival by $\sim 0.1 \mathrm{~s}$ (left arrow) and the high-velocity arrival with inverted phase that is tangent to the first arrival (right arrow).

the start of Expedition 309 [Expedition 309/312 Scientists, 2006]:

$$
\begin{aligned}
\text { temperature }\left({ }^{\circ} \mathrm{C}\right)= & 16.25+(\text { depth }-250) \\
& * 0.0348 \text { above } 1061 \mathrm{mbsf} \\
\text { temperature }\left({ }^{\circ} \mathrm{C}\right)= & 44.50+(\text { depth }-1061) \\
& * 0.0950 \text { below } 1061 \mathrm{mbsf}
\end{aligned}
$$

\subsection{Vertical Seismic Profiles}

[8] Leg 206 and Expedition 312 acquired vertical seismic profiles (VSP) to obtain vertical one-way traveltimes at seismic wavelengths [Shipboard Scientific Party, 2003b, Expedition 309/312 Scientists, 2006]. Although the two VSPs used different receivers and source configurations producing significantly different seismograms, the velocity profiles that we determined are very sim- ilar. Leg 206 used the Schlumberger Well Seismic Tool as the receiver, but Expedition 312 used the Schlumberger Versatile Seismic Imager tool. On Leg 206 a generator-injection air gun hung at $2 \mathrm{~m}$ below sea level (mbsl) was configured in harmonic mode with a $105 \mathrm{~cm}^{3}$ generator chamber and a $105 \mathrm{~cm}^{3}$ injector chamber, whereas during the Expedition 312 VSP the same air gun was hung at $7 \mathrm{mbsl}$ and configured in harmonic mode with a $150 \mathrm{~cm}^{3}$ generator chamber and a $150 \mathrm{~cm}^{3}$ injector chamber. This reconfiguration moved peak power from $50-300 \mathrm{~Hz}$ to $<75 \mathrm{~Hz}$. Clamping depths for the receiver were spaced $\sim 40 \mathrm{~m}$ on Leg 206 and $\sim 22 \mathrm{~m}$ on Expedition 312, but borehole washouts forced spacing to deviate by up to $50 \%$. On Expedition 312 we clamped at 59 borehole depths, but traveltimes could be reliably picked for seismograms at only 48 depths. Signal/noise ratio depends 


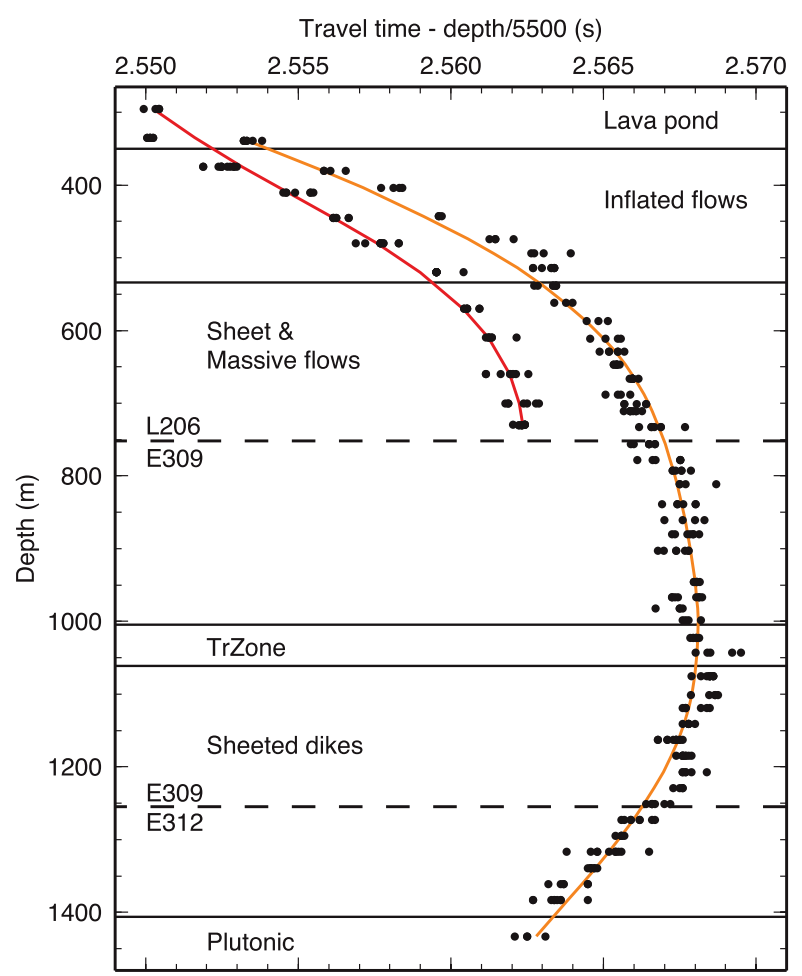

Figure 3. Traveltimes picked on the best quality seismograms from both VSPs were fit by inversion following Lizarralde and Swift [1999]. Owing to high noise caused, presumably, by unstable borehole wall condition, seismograms for 11 of 59 clamping stations during Expedition 312 were not picked. For the inversion of the Leg 206 traveltimes, we used epsilon $=8.4$ (red). For the inversion of the Expedition 312 traveltimes, we used epsilon $=111$ (orange).

mostly on the quality of tool clamping at each receiver depth and is similar for the two VSPs.

[9] Figure 2 shows stacked VSP seismograms for Leg 206 and Expedition 312. We picked traveltimes for the first peak in the traces with the best signal/noise at each receiver depth used (Figure 3). Traveltime precision is $0.2 \mathrm{~ms}$, but times for one receiver station typically range over $1 \mathrm{~ms}$, which is $20-30 \%$ of the difference in the mean traveltime between many pairs of receiver stations. Thus, picking errors alone may contribute $\sim 1 \mathrm{~km} / \mathrm{s}$ uncertainty if the traveltime means are used to compute velocity. To reduce this effect, traveltimes were inverted for velocity using an approach adapted for vertical seismic profiles by Lizarralde and Swift [1999]. A single damping parameter, epsilon, controls the tightness of fit to the traveltime means. If epsilon is near zero, the inversion provides a fit that closely follows the traveltime means at each receiver depth. Following Constable et al. [1987], Lizarralde and Swift [1999] suggested an objective rationale for choosing epsilon based on the chisquare distribution of the traveltime residuals. We use values of epsilon that give chi-square residual error equal to the number of receiver depths in each VSP (Leg 206 epsilon $=8.4$, Expedition 312 epsilon $=111)$. This fit dampens traveltime fluctuations over scales of 100-200 m (Figure 3). At most depths the results from the two VSPs agree to within $0.2 \mathrm{~km} / \mathrm{s}$ (Figure 4). The velocity difference at the top of Hole 1256D is due to smoothing of the top of the Leg 206 VSP profile with a high interval velocity obtained in the massive flow comprising the Lava Pond unit (Figure 3). A table of traveltimes and velocities for each VSP is available in the auxiliary materials ${ }^{1}$.

\section{Results}

[10] At the top of the borehole, sonic log velocity increases from $4.8 \mathrm{~km} / \mathrm{s}$ in cased sheet flows at the basement surface to $5.5 \mathrm{~km} / \mathrm{s}$ throughout the massive flow comprising the Lava Pond unit (265$345 \mathrm{mbsf}$ ) and then abruptly decreases to $4.1 \mathrm{~km} / \mathrm{s}$ at the top of the Inflated Flow unit $(350 \mathrm{mbsf})$. Below the Lava Pond unit, velocity varies by up to $1.5 \mathrm{~km} / \mathrm{s}$ over tens of meters and increases at an overall gradient of $\sim 2 \mathrm{~km} / \mathrm{s}$ per $\mathrm{km}$ to $6.2-6.8 \mathrm{~km} / \mathrm{s}$ at the top of the plutonic section (1407 mbsf).

[11] Velocities from the VSPs generally agree with sonic log velocities, but significant discrepancies occur in the Inflated Flow unit and at the base of the sheeted dikes (Figures 4 and 5). At the top of basement, there is good agreement between velocities from all methods except the refraction profile. Traveltimes in the massive flow comprising the Lava Pond unit from the upper two seismometer stations of the Leg $206 \mathrm{VSP}$ give $5.5 \mathrm{~km} / \mathrm{s}$ (magenta line in Figure 5), which agrees well with both laboratory measurements on minicubes and the borehole sonic log. In this interval, however, the refraction profile is $0.7 \mathrm{~km} / \mathrm{s}$ slower. VSP and borehole velocities drop to $4.2 \mathrm{~km} / \mathrm{s}$ in the top of the Inflated Flow unit (350-400 mbsf). In the lower half of the Inflated Flow unit, however, velocities from the sonic $\log$ and minicubes increase to $5.6 \mathrm{~km} / \mathrm{s}$, whereas velocities from both VSPs remain $\sim 1.3 \mathrm{~km} / \mathrm{s}$ lower. This is the greatest discrepancy between velocities determined at seismic scales using VSP arrivals and velocities determined at borehole scales by wireline and laboratory measurements. The refraction velocity profile aver-

${ }^{1}$ Auxiliary materials are available in the HTML. doi:10.1029/ 2008GC002188. 


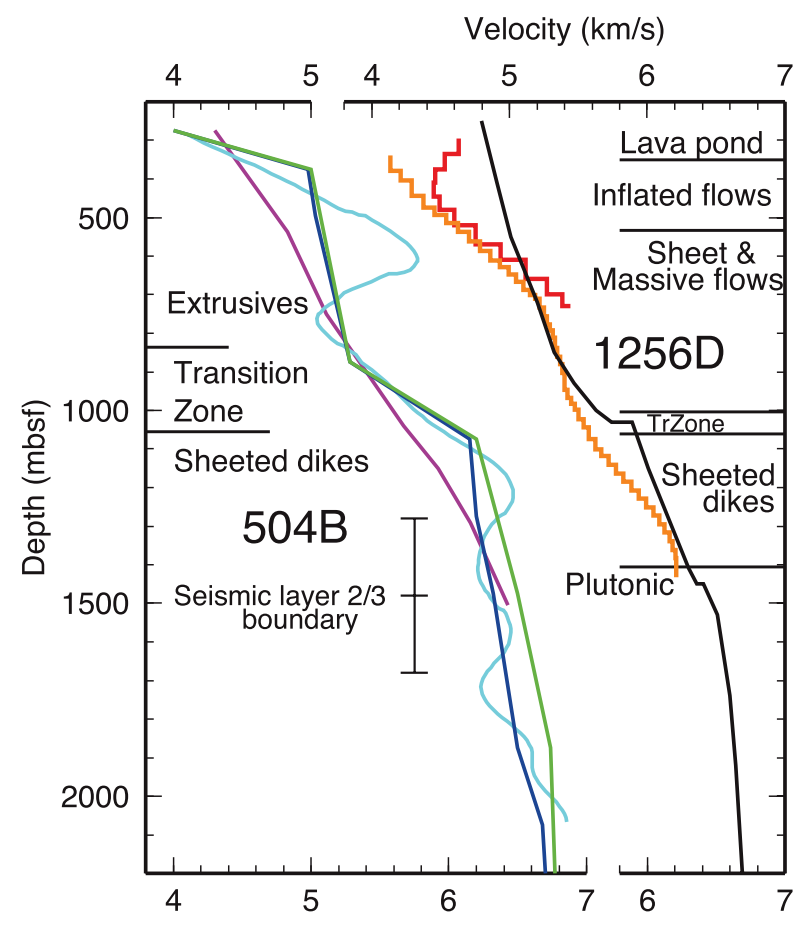

Figure 4. The seismic velocity profiles (right) collected at Hole 1256D (15 Ma and $220 \mathrm{~mm} / \mathrm{a}$ full spreading rate) are very similar to profiles (left) collected at 504B (6.6 Ma, $98 \mathrm{~mm} / \mathrm{a}$ full spreading rate). The results at Hole 504B include profiles from inversion of borehole seismometer traveltimes (magenta) [Little and Stephen, 1985], forward modeling an ocean bottom seismometer record (blue) [Collins et al., 1995], tomographic inversion of traveltimes to 11 ocean bottom seismometers (green) [Detrick et al., 1998], and inversion of VSP traveltimes (light blue) [Swift et al., 1998a]. The depth of the seismic layer $2 / 3$ boundary and error bars is taken from Detrick et al. [1994]. The results at Hole 1256D include inversion of an ocean bottom hydrophone seismic profile (black, "NE" profile in the work of Shipboard Scientific Party [2003a]; A. Harding, personal communication, 2008) and inversion traveltimes from the Leg 206 VSP traveltimes (red) and the Expedition 312 VSP (orange).

ages through the discrepancy. In the lower part of the extrusive lava sequence, smaller differences of $\sim 0.8 \mathrm{~km} / \mathrm{s}$ between VSP and sonic log velocities occur in 20-30 m thick layers at about 680 and $880 \mathrm{mbsf}$. At the dike-gabbro boundary, the VSP velocity drops $0.6-0.7 \mathrm{~km} / \mathrm{s}$ below the sonic $\log$. This discrepancy is intriguing, but we judge the observation to be unreliable because it is based on arrival times from the deepest VSP receiver station where clamping was poor and the signal/noise ratio is relatively low.

[12] Depth plots of physical properties measured on minicubes at sea (Figure 6) show apparent correlations among the various properties. Bulk density, velocity, and thermal conductivity are positively correlated. Porosity varies inversely with the other three properties and decreases to very low values between $1275 \mathrm{mbsf}$ and the top of the gabbros.

[13] In general, velocities from shipboard measurements on minicubes agree with the sonic log despite the differences in sound frequency and pressure. Discrepancies only occur at two depth intervals. In the 550-750 mbsf interval at the top of the Sheet and Massive Flows unit, many of the velocities from minicubes systematically exceed the average sonic log (Figure 5). This discrepancy is probably not significant because the difference $(0.3-0.4 \mathrm{~km} / \mathrm{s})$ is relatively small and the laboratory samples are within the range of the unsmoothed sonic log. It is likely that the only minicubes that could be cut from core samples in this interval were representative of the small fraction of the drilled interval that was free of cracks and alteration minerals, which cannot be regarded as representative of this interval (Shipboard Scientific Party [2003b], especially Figures F99, F130, and F133). A more serious discrepancy occurs at the base of the sheeted dikes. Near $1275 \mathrm{mbsf}$ and $1325 \mathrm{mbsf}$, the sonic log jumps $0.2-0.3 \mathrm{~km} / \mathrm{s}$ and then increases at $\sim 3 \mathrm{~km} / \mathrm{s}$ per $\mathrm{km}$, whereas velocities from minicubes fluctuate but increase little with depth (Figures 5 and 7). Across the top of the upper gabbro unit, velocities from minicubes decrease to $5.4-5.8 \mathrm{~km} / \mathrm{s}$, but sonic $\log$ velocities remain at $6.6-6.8 \mathrm{~km} / \mathrm{s}$. Despite these discrepancies, there is remarkable agreement between velocities measured on minicubes at sea level pressure and velocities measured in situ over path lengths of meters.

[14] Velocities from minicubes decrease abruptly at three depths in the sheeted dikes and at the top of the two gabbro units (Figure 7). At 1050 in the Transition Zone and at 1155 and 1325 mbsf in the sheeted dikes, both minicube velocity and sonic log velocity decrease coincident with peaks in magnetic susceptibility and a change in trend in the resistivity log (Figure 8). At 1050 mbsf, major changes also occur in density and porosity logs. At 1325 mbsf, sonic log velocity reaches a minor low, magnetic susceptibility is high, and the variability in the resistivity, porosity, and density $\operatorname{logs}$ decreases noticeably. At the top of the gabbro units, grain size increases dramatically and magnetic susceptibility spikes, but there is no apparent change in sonic log velocity at the top of the 


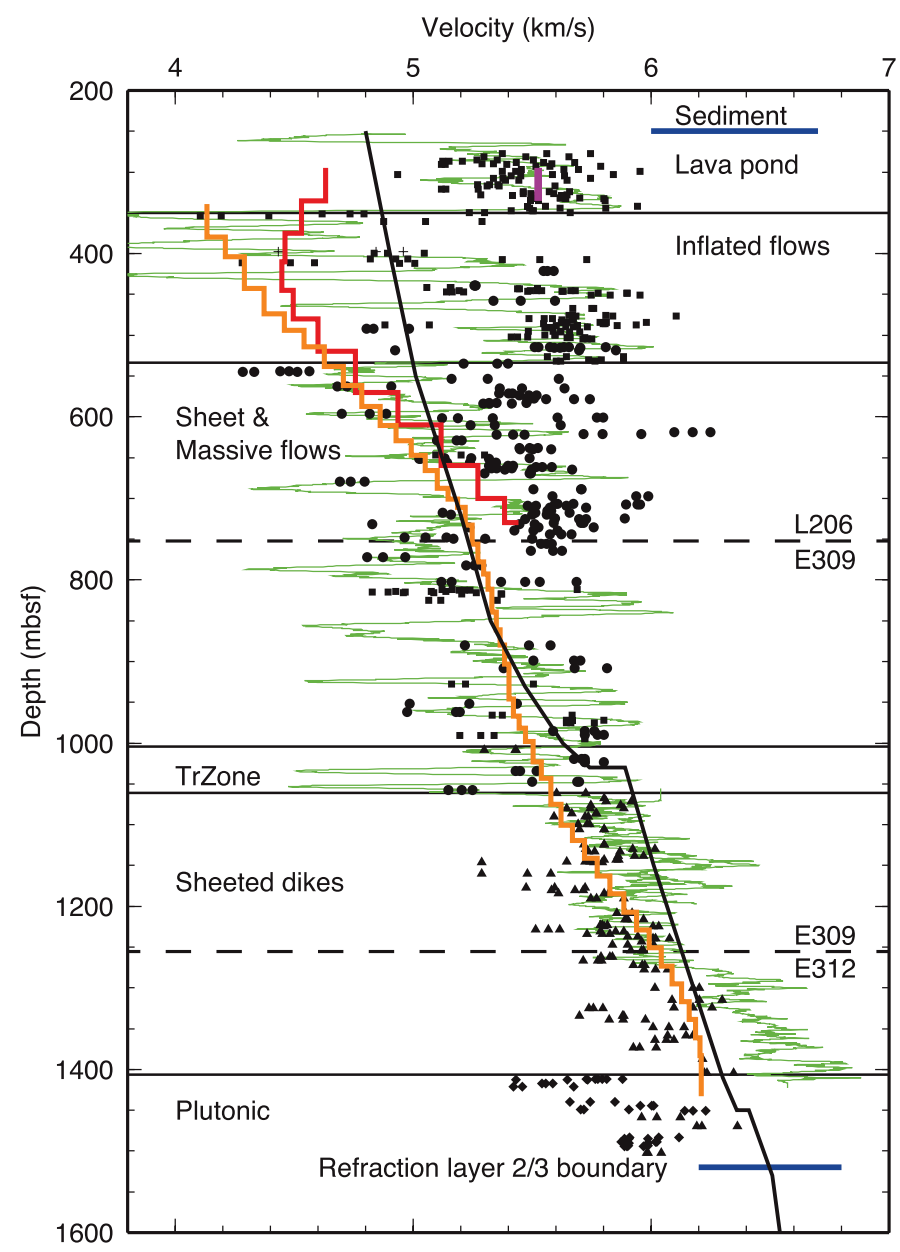

Figure 5. Velocity results at Hole 1256D include measurements made in the JOIDES Resolution laboratory on minicubes (black squares, massive flows; circles, sheet flows; crosses, breccia; triangles, dikes; diamonds, gabbros), sonic logs (green) from Expeditions 309 and 312 smoothed with a $6.8 \mathrm{~m}$ moving average, and the inversion of traveltimes from the Leg 206 VSP traveltimes (red) and the Expedition 312 VSP (orange). The depth of the seismic layer $2 / 3$ boundary is based on the change in gradient in the refraction velocity profile near $1520 \mathrm{mbsf}$ and has uncertainty similar to the uncertainty at Hole 504B ( \pm 200 m, Figure 4) [Detrick et al., 1994; Swift et al., 1998a] due to the low-frequency and long wavelengths of refracted energy at this depth.

shallower gabbro unit. Thus, the six minima in minicube velocity occur at depths at which in situ physical properties also change.

[15] Two of these abrupt changes in physical properties correlate with changes in mineralogy determined in thin sections during Expedition 312. Figure 9 shows that the drop in velocity of $0.4 \mathrm{~km} / \mathrm{s}$ at $1325 \mathrm{mbsf}$ coincides with an increase in clinopyroxene, magnetite and, perhaps, actinolite, whereas mesostasis disappears. The appearance of secondary hornblende occurs below this horizon at the top of the granoblastic dikes (1348 mbsf). Not surprisingly, several mineralogy changes coincide with the abrupt drop in velocity $(0.9 \mathrm{~km} / \mathrm{s})$ at the top of the upper gabbro (1407 mbsf). However, no changes in mineralogy occur at the top of the lower gabbro where velocity drops by only $0.3-$ $0.4 \mathrm{~km} / \mathrm{s}$.

[16] The amount of variability in minicube velocity and sonic log velocity changes with depth (Figure 5). For both, the amplitude of fluctuations is high (1$2 \mathrm{~km} / \mathrm{s}$ over $25-50 \mathrm{~m}$ ) in the extrusive section and decreases by a factor of 2-3 at the base of the Transition Zone (1060 mbsf). In the upper dikes (1060-1350 mbsf) compressional velocities from both minicubes and sonic logs vary $<0.8 \mathrm{~km} / \mathrm{s}$ over $10-15 \mathrm{~m}$. Peak-to-peak variations in shear velocity decrease to $<0.4 \mathrm{~km} / \mathrm{s}$ (Figure 10). This trend does not continue to the base of the dikes. Below 1275 mbsf, shear velocity fluctuations more than double. As described above, however, these large fluctuations may be artifacts. 

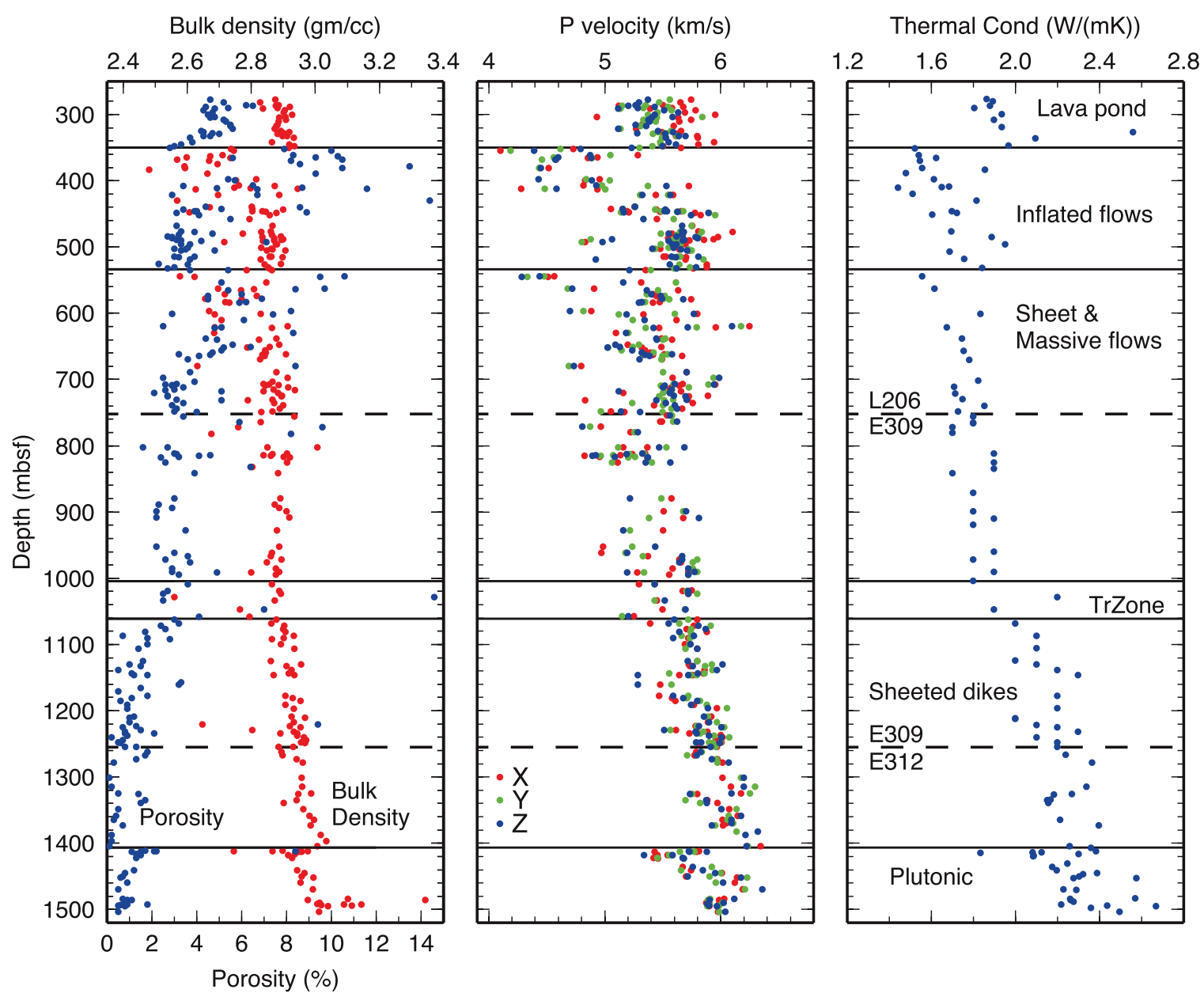

Figure 6. (a) Measurements made aboard the JOIDES Resolution on minicubes of porosity (blue) are inversely correlated to measurements of density (red), (b) sonic velocity, and (c) thermal conductivity. Variability is greater in the eruptive lava sequence above 1000 mbsf.

[17] In the VSP record section, we cannot detect arrivals with phase velocities of shear waves $(<4 \mathrm{~km} / \mathrm{s})$ similar to those in the VSP data from Hole 504B [Swift et al., 1998a]. Shear velocities from the sonic log allow us to compute Poisson's ratio, a measure of the relative rigidity and compressibility in the rock surrounding the borehole (Figure 10). In the Lava Pond and Inflated Flow units (250-530 mbsf), values of Poisson's ratio are within typical crustal values $(0.24-0.32)$ but range up to 0.4 in $10-20 \mathrm{~m}$ thick intervals $(0.2-0.4)$. Values vary less in the Sheet and Massive Flows unit and average 0.27. These results at shallow depths are lower than Poisson's ratio determined for Hole 504B using VSP velocities despite the difference in scale and resolution [Swift et al., 1998a]. In the sheeted dikes, shear velocity increases and Poisson's ratio decreases reaching an average value of $0.23-0.24$ at $1250 \mathrm{mbsf}$.
Below 1275 mbsf, the shear velocity log is unreliable, and Poisson's ratio is uncertain.

[18] With the exception of the upper $450 \mathrm{~m}$ of basement (250-700 mbsf), the refraction velocity profile generally agrees with VSP results and the sonic log. Between the Lava Pond and Inflated Flow units, VSP velocity decreases by $1.5 \mathrm{~km} / \mathrm{s}$ (Figure 5); the refraction profile averages through this change in velocity. The difference is likely due to the difference in propagation direction and frequency. The refraction experiment used source energy $<20 \mathrm{~Hz}$ traveling horizontally with wavelengths of 300-500 m whereas the Leg 206 VSP experiment used a source peaking at $50-300 \mathrm{~Hz}$ that traveled vertically. Below $700 \mathrm{mbsf}$, velocities from the refraction profile differ by $<0.2 \mathrm{~km} / \mathrm{s}$ from VSP velocities (Figure 5). In the Transition Zone (1004-1061 mbsf), modeling of a wide-angle reflection pulls refraction velocities $\sim 0.2 \mathrm{~km} / \mathrm{s}$ 


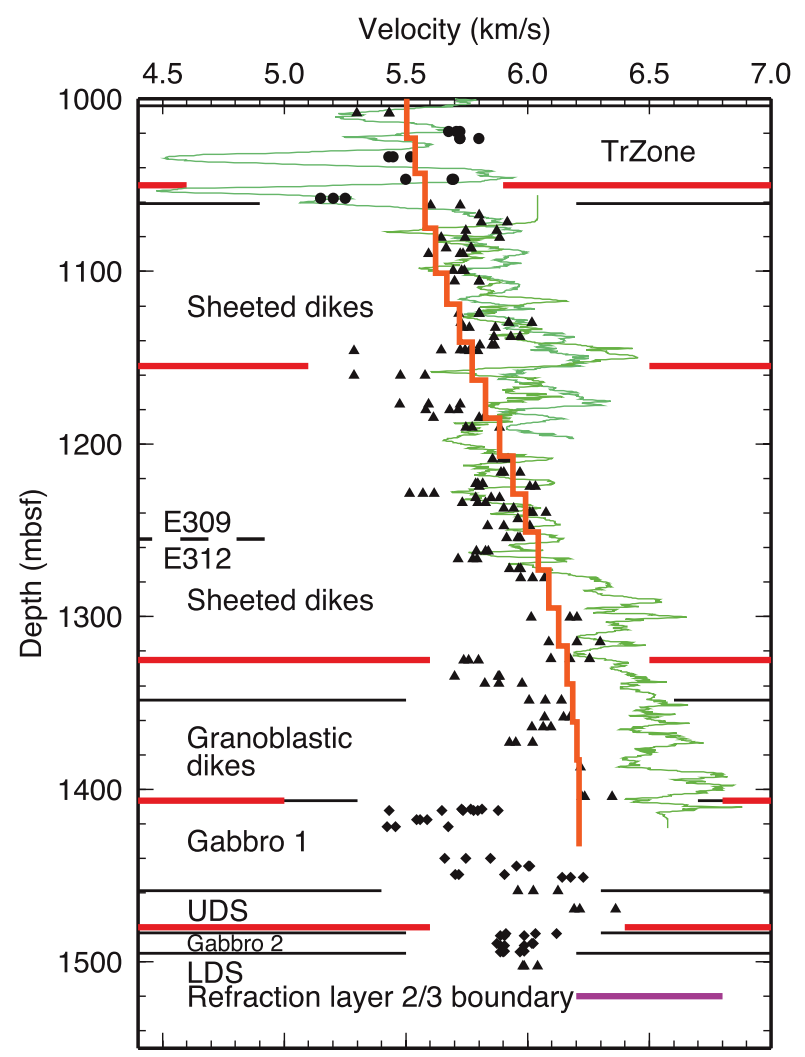

Figure 7. Velocities measured on minicubes from the dikes and gabbros in Hole 1256D (black, see caption of Figure 5 for symbols) decrease abruptly at five depth horizons (red horizontal lines). The sonic log (Expedition 309, cyan, Expedition 312, green) decreases at the two shallowest horizons (1050 and $1155 \mathrm{mbsf}$ ) and increases at the next two deeper horizons (1325 and $1407 \mathrm{mbsf}$ ). The VSP velocity profile (orange) changes little at the horizons except for a change in gradient coincident with the 1325 mbsf horizon.

higher than VSP velocities. In general, there is remarkably good agreement between all data sets.

\section{Discussion}

\subsection{Evidence for Microfractures}

[19] One of more remarkable features of the velocity results from Hole $1256 \mathrm{D}$ is the relatively close agreement between the smoothed sonic log and the shipboard laboratory velocities down to $\sim 1275 \mathrm{mbsf}$ (Figure 5). The sonic logs appear unaffected by the presence of the borehole and reflect in situ pressure conditions because differences between VSP velocities and mean sonic velocity above and below the Inflated Flow Unit ( $>530 \mathrm{mbsf})$ are $<0.2-$ $0.3 \mathrm{~km} / \mathrm{s}$. (The velocity disagreement in the Inflated Flow unit is discussed below.) We infer, then, that our laboratory velocities are representative of in situ conditions down to at least $1275 \mathrm{mbsf}$ and that the effects on velocity above this depth from fractures on scales greater than the shipboard minicubes is minimal. We attribute closing of larger fractures principally to deposition of hydrothermal minerals.

[20] These data (Figure 5) indicate that laboratory velocities of samples at borehole depths $<1275 \mathrm{mbsf}$ are similar to in situ velocities despite the effects of sampling by rotary drilling and changes in pressure. In many cores, samples were recovered in pieces. At least some of this breakage is due to fracturing by drill bit rotation and cooling by drilling fluid. Drilling effects were largely avoided by sampling rock pieces that reached the ship's laboratory with no visible fractures, a strategy employed so minicubes would remain intact during cutting by the laboratory saw. As a result, our samples are inherently biased to rocks that are least deformed by drilling.

[21] The effects of pressure release are more problematic. Empirically, the good agreement between the shipboard laboratory velocities and the sonic log velocities indicates that intact borehole samples accommodate expansion without creating significant fracture porosity and without altering the velocity. There is evidence from the Kola well in Russia that diabases resist microfracturing when recovered from similar pressures. On the basis of microscopic examination and permeability measurements, Morrow et al. [1994] report an absence of microfractures in a diabase and a metadiabase sample recovered from $936 \mathrm{~m}$ and $2948 \mathrm{~m}$, respectively, in the Kola well, whereas granodiorites from the Kola well show evidence of microfracturing. Morrow et al. [1994] ascribe the absence of microfracturing in their diabases to small grain size, absence of quartz, and shallower sample depth. Effective in situ pressures for these samples (18 and $56 \mathrm{MPa}$ ) reported by Morrow et al. [1994] are similar or greater than the effective pressure at $1275 \mathrm{mbsf}$ in Hole $1256 \mathrm{D}$ (17 MPa, Figure 11). We infer that the diabases that we sampled above $1275 \mathrm{mbsf}$ are strong enough to resist fracturing during expansion.

[22] Below 1275-1325 mbsf velocities measured in the shipboard laboratory diverge from in situ sonic $\log$ velocities by $0.2-0.5 \mathrm{~km} / \mathrm{s}$ (Figure 5). The divergence occurs at the same depth at which both laboratory porosity and in situ porosity values computed from resistivity drop to very low values less than $0.5 \%$ (Figures 6 and 8 ). One hypothesis to explain this coincidence is that the strain of expansion and cooling in diabase with porosity $<0.5 \%$ 


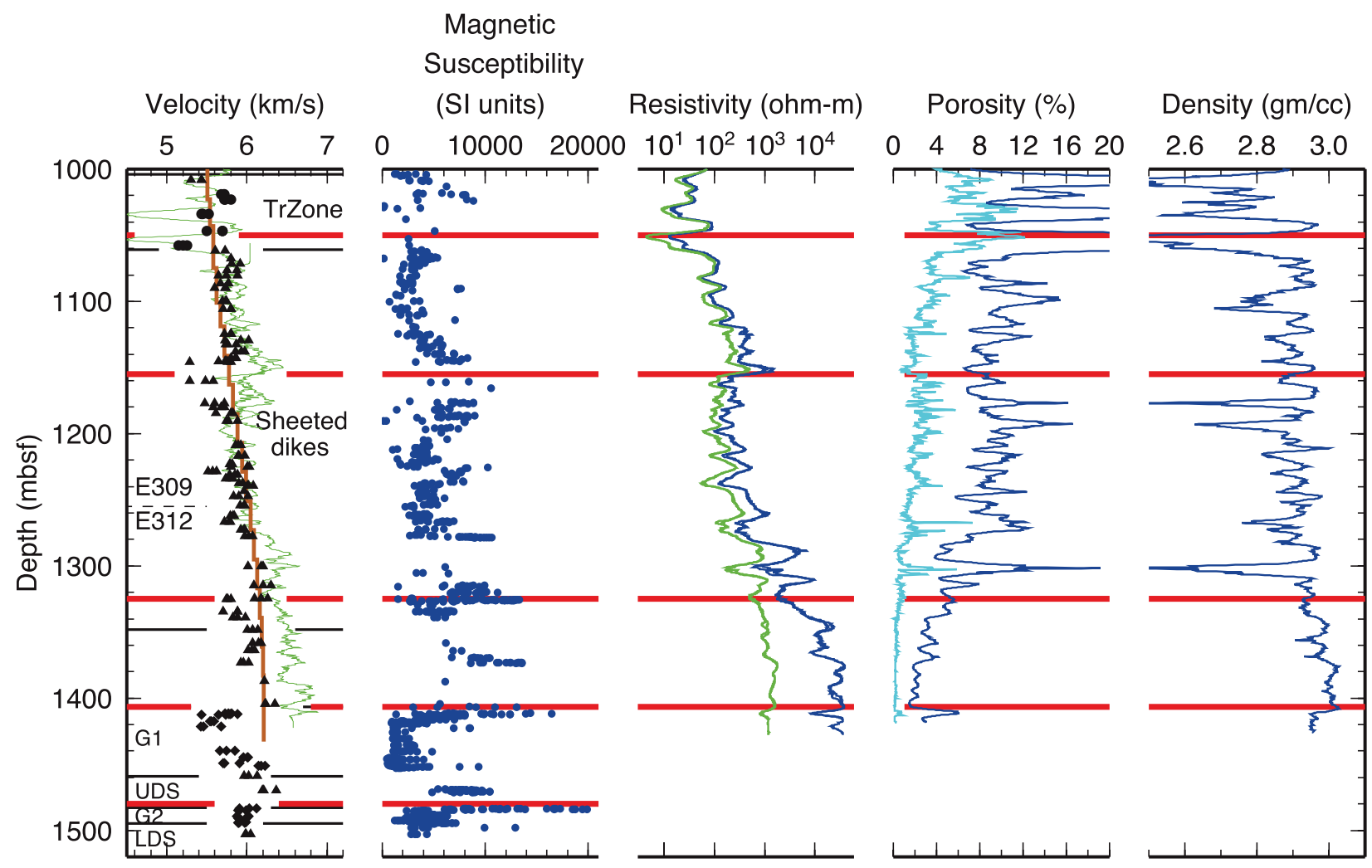

Figure 8. The depth horizons (red) at which the velocities measured on minicubes (black symbols) decrease abruptly coincide with abrupt changes in either the amplitude or the vertical gradient of magnetic susceptibility measured on core pieces $>8 \mathrm{~cm}$ and with changes in the smoothed resistivity logs (blue is deep DLL log and green is shallow DLL log) and porosity logs (dark blue is neutron porosity and light blue is porosity computed from resistivity $\log$ ). Changes in the smoothed density log at the horizons are minor except for the abrupt decrease at $1050 \mathrm{mbsf}$. At left, laboratory velocities are black (black squares, massive flows; circles, sheet flows; crosses, breccia; triangles, dikes; diamonds, gabbros), green is smoothed sonic log, and orange is the Expedition 312 VSP.

affects velocity properties of these rocks more than such strain affects samples with higher original porosity. A simple change in the mechanical strength of the rock cannot explain these results because laboratory measurements predict the opposite effect. Moos and Pezard [1996] found that the unconfined compressive strength of diabases from Hole 504B with porosities less than 1\% exceeds the strength of rocks with lower porosities. No significant changes in mineralogy occur at 1275-1325 mbsf indicative of a compositional reason for a change in physical properties (Figure 9). We suggest that the diabases from $>1275$ mbsf differ from shallower rocks in that most pores and fractures are not interconnected. If pores in rocks at depths $>1275$ mbsf are isolated, vertical stress due to the overlying rock is unbalanced by hydrostatic pressure. Thus, the pressure release when these rocks are drilled is the lithostatic pressure (67 MPa) rather than the effective pressure at this depth (17 MPa, Figure 11). We suggest that this stress exceeds the elastic limit of the rock, so micro- fractures form in the diabase. In addition, high fluid pressure in small, unconnected pores in the rock will expand when the lithostatic load is released and may induce hydrofracture creating additional fractures. The fractures from both mechanisms reduce the velocity of the rock measured in the laboratory. These hypotheses predict different deformation patterns in rocks recovered from above and below 1275 mbsf that can be tested with further shore-based study. Our conjecture that the intergranular pores in the diabase below 1275$1325 \mathrm{mbsf}$ are not connected implies that hydrothermal fluid no longer flows through portions of the formation not adjacent to faults and fissures that have remained open to circulation.

\subsection{Inferred Lateral Variability}

[23] The emplacement of basalt forming seismic layer $2 \mathrm{~A}$ on super-fast spreading ocean crust comprises lava flows erupted on axial domes and troughs [e.g., Renard et al., 1985; Auzende et al., 

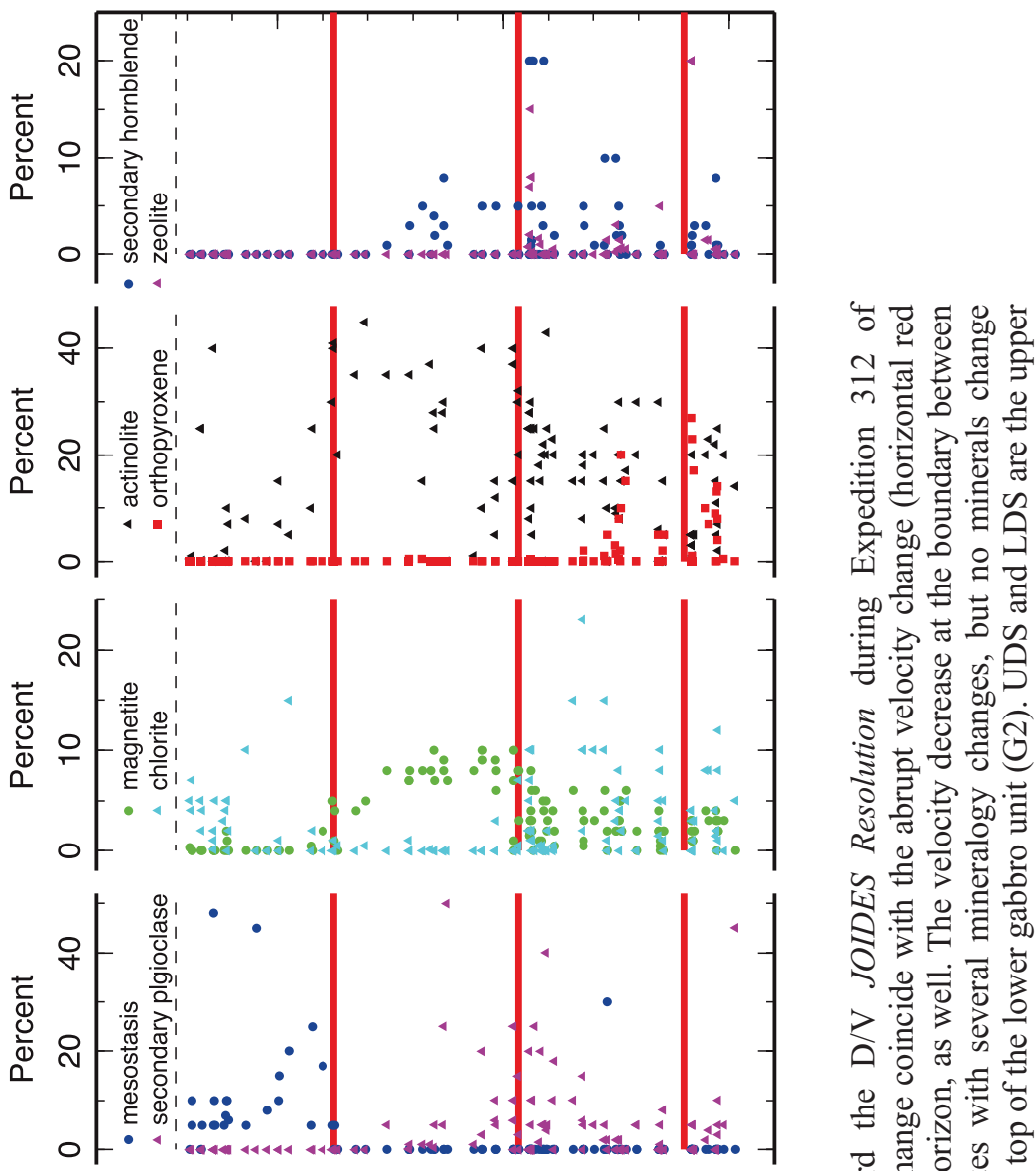

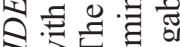

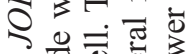

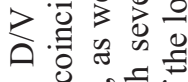

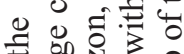

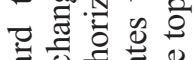

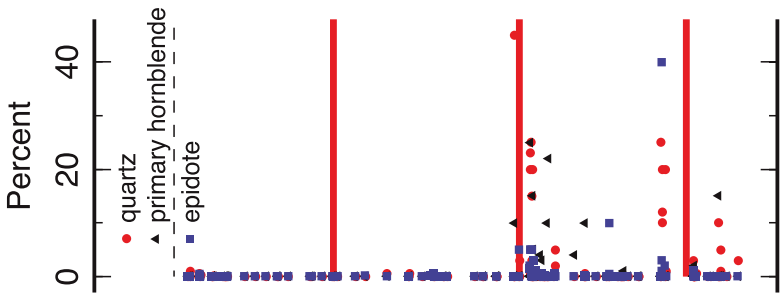

을

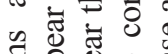

.0 을

过

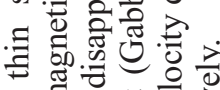

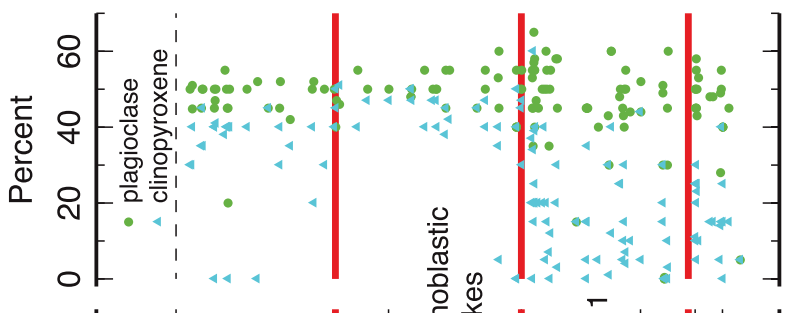

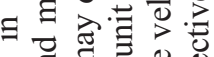

๑

艺.

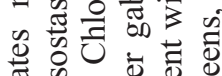

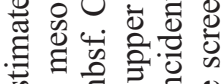

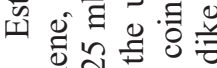

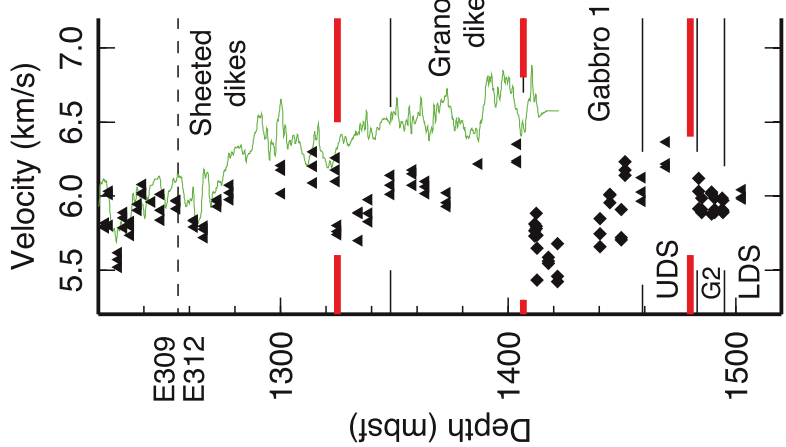

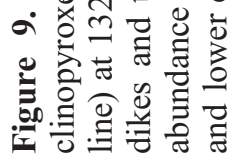




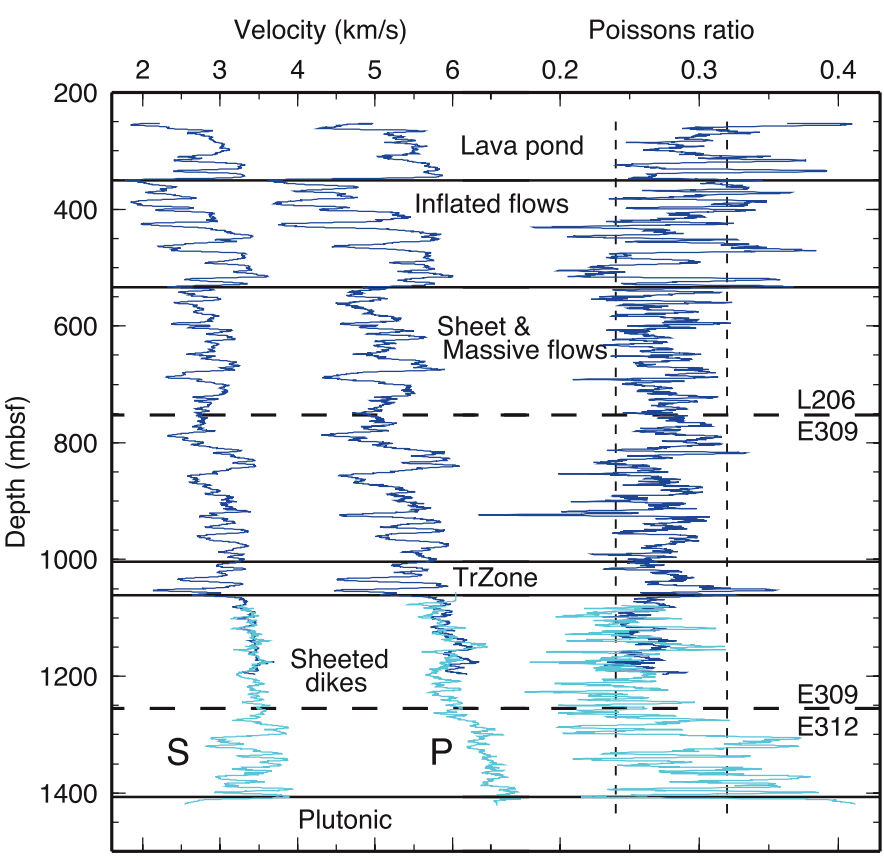

Figure 10. In the shallowest extrusive flow units above $\sim 550 \mathrm{mbsf}$, Poisson's ratio determined from the smoothed compressional (P) and shear (S) velocity logs is variable and often higher than typical crustal values (0.24-0.32; vertical dashed lines) [Spudich and Orcutt, 1980]. In the Sheet and Massive Flow unit and the Transition Zone, Poisson's ratio varies very little outside the normal ocean crustal range. Poisson's ratio decreases slightly to $\sim 0.25$ in the upper Sheeted Dikes. Fluctuations below $1250 \mathrm{mbsf}$ are suspect because the shear velocities at these depths are unreliable.

1996; Embley et al., 1998; Lagabrielle and Cormier, 1999; White et al., 2000; Wright et al., 2002; Sinton et al., 2002] and those that erupt or extend off-axis [Macdonald et al., 1989]. Topography is one important factor in construction of the volcanic stratigraphy and, thus, the permeability that controls subsequent hydrothermal circulation and alteration. For example, fissures, fault scarps, previous flows, lava channels, and collapse features may constrain the flow of lava. We show that these structures also contribute to lateral variability in seismic velocity properties of uppermost ocean crust.

[24] To infer velocity properties of crustal rocks, ocean drilling VSPs use a sound source with spectral characteristics similar to underway geophysics surveys. At crustal depths the wavefront from a shot is very broad with little curvature, so its arrival time and amplitude are affected by material properties of rocks well beyond the borehole [Swift et al., 1996]. As a result, significant lateral variability in rock types and properties will produce disagreements between VSP velocities and velocities determined in the borehole by logging or in the laboratory on rock samples. For example, an anomalously fast rock type may occur near the borehole but not be sampled by coring or logging. The fast rock may speed the wavefront from the air gun. Seafloor observations [e.g., Karson et al., 2002] demonstrate variability in the internal structure of the volcanic layer on scales of $10-100$ s of meters, so these so-called Freznel zone effects [Hardage, 1983, pp. 286-292] may be common. We examine two portions of Hole 1256D in detail.

\subsubsection{Lava Pond Unit}

[25] The velocity of the Lava Pond unit (250$350 \mathrm{mbsf}$ ) differs from the extrusive units just below in that all methods except seismic refraction give similar velocities of $5.5 \mathrm{~km} / \mathrm{s}$ (Figure 4). Since shallow refracted arrivals $(10 \mathrm{~Hz})$ travel horizontally with wavelengths of $\sim 500 \mathrm{~m}$, the speed of refracted arrivals is likely slowed by lower velocities at depths $>350$ mbsf (i.e., $>100 \mathrm{~m}$ in basement). At Hole 1256D the Lava Pond unit comprises a single massive flow with thickness $>74 \mathrm{~m}$ [Shipboard Scientific Party, 2003b; Tartarotti et al., 2006]. The stratigraphy in Figure 12 shows that compressional velocity from the sonic $\log$ in the upper $15 \mathrm{~m}$, recorded through steel casing at the top of the hole, drops to $4.2-4.8 \mathrm{~km} / \mathrm{s}$, probably due to thin sheet flows with high interflow porosity similar to flows 


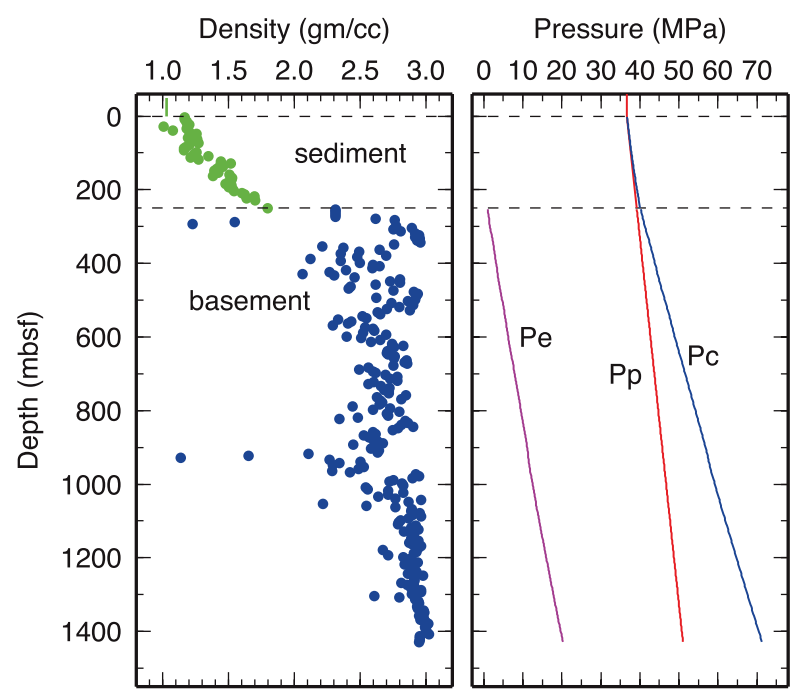

Figure 11. The effective pressure ( $\mathrm{Pe}$, magenta line) reaches about $20 \mathrm{MPa}$ at the base of Hole 1256D. Effective pressure is computed as the difference between confining (total overburden) pressure (Pc, blue line) and pore pressure ( $\mathrm{Pp}$, red line), which are computed from an assumed density of water (green line: $1.028 \mathrm{~g} / \mathrm{cc}$ ), the shipboard laboratory measurements of sediment density averaged in $5 \mathrm{~m}$ bins (green dots), and the density log measured on Expedition 312 averaged in $5 \mathrm{~m}$ bins (blue dots).

recovered at the same depth in nearby Hole $1256 \mathrm{C}$. There are no VSP receiver stations within the upper $25 \mathrm{~m}$ of Hole 1256D due to casing, so VSP results cannot confirm the continuation of the $35 \mathrm{~m}$ sequence of sheet flows from the top of basement at Hole 1256C. Below $\sim 300 \mathrm{mbsf}$, the similarity between the VSP velocity derived from vertically traveling, low-frequency (Leg 206: 50-300 Hz) air gun signals and velocities from high-frequency measurements at the borehole (minicubes, $500 \mathrm{kHz}$, and sonic $\log , 80 \mathrm{~Hz}$ to $5 \mathrm{kHz}$ ) is probably due to low fracture porosity and lateral continuity of both rock type and structure. An area much larger than the borehole influences downward propagation of VSP energy traveling at seismic wavelengths. Typically, this region is defined by the first Freznel Zone: the area over which the first half wavelength of the spherically propagating wavefront is in contact with a depth horizon [Sheriff and Geldart, 1982; Hardage, 1983]. For a wave traveling vertically, the radius of this area at the seafloor is $18-108 \mathrm{~m}$ for the Leg 206 VSP and 160-200 m for the Expedition 312 VSP, with the difference due to the different sound source spectrums. The radius increases with depth as rock velocity increases. The agreement in velocity between the different methods indicates that the Lava Pond unit extends for at least $300-400 \mathrm{~m}$. This uniformity is consistent with flat basement topography extending for several kilometers around Hole 1256D [Hallenborg et al., 2003; Shipboard Scientific Party, 2003b].

[26] Velocity in the massive Lava Pond unit $(5.5 \mathrm{~km} / \mathrm{s})$ is high for uppermost basement of fast spreading ocean crust. At Site 1243 (10-12 Ma, 140 mm/a full spreading rate) velocities at the top of basement from logging and VSPs are $4.5-5.0 \mathrm{~km} / \mathrm{s}$ [Shipboard Scientific Party, 2003c; Carlson, 2004], and at Hole 504B (7 Ma, $95 \mathrm{~mm} / \mathrm{a}$ full spreading rate [Swift et al., 1998b, Figure 14]) velocities are $4.0-4.5 \mathrm{~km} / \mathrm{s}$ [Little and Stephen, 1985; Swift et al., 1998a; Detrick et al., 1998]. Upper basement at these sites comprises pillow basalts and a few, thin sheet flows. Low seismic velocities commonly found at the basement surface are ascribed to fracture porosity [e.g., Hyndman and Drury, 1976]. The inverse occurs at Site 1256. Figure 12 (left) show that the sonic log in Hole 1256D varies inversely with the porosity log, and velocity is high in low-porosity massive flows like that forming the Lava Pond. Thus, the unusually high seismic refraction velocity at the basement surface (black line in Figure 12) results from a single thick massive volcanic flow. The VSP stations are widely spaced, but VSP velocities generally agree with velocities from the sonic logs (Figures 4 and 12). In the Lava Pond unit, Poisson's ratio is within the bounds for typical ocean crust (Figure 10) and, thus, much lower than values often measured in uppermost crust [Hyndman, 1979; Swift et al., 1998a]. The low Poisson's ratio values suggest a lack of fracturing, indicate that the unit postdates tectonic stress that accompanies spreading at the ridge axis, and confirm the interpretation by Shipboard Scientific Party [2003b] that the shallowest $100 \mathrm{~m}$ of basement was emplaced off-axis. Assuming that smooth, flat basement topography and bathymetry indicates the region covered by the lava flow, high basement velocities found at Hole 1256D are limited in lateral extent. These results indicate that off-axis flows may contribute up to $1.0 \mathrm{~km} / \mathrm{s}$ of the variability in the velocity structure of upper basement described by Raitt [1963].

\subsubsection{Inflated Flow Unit}

[27] The Inflated Flow unit is characterized by large vertical changes in velocity with sonic log velocity varying vertically by almost $2 \mathrm{~km} / \mathrm{s}$ (Figure 13). These variations appear to correlate well with vertical changes in porosity associated with different types of flows. Different velocities determined by different methods also indicate lateral variations in 

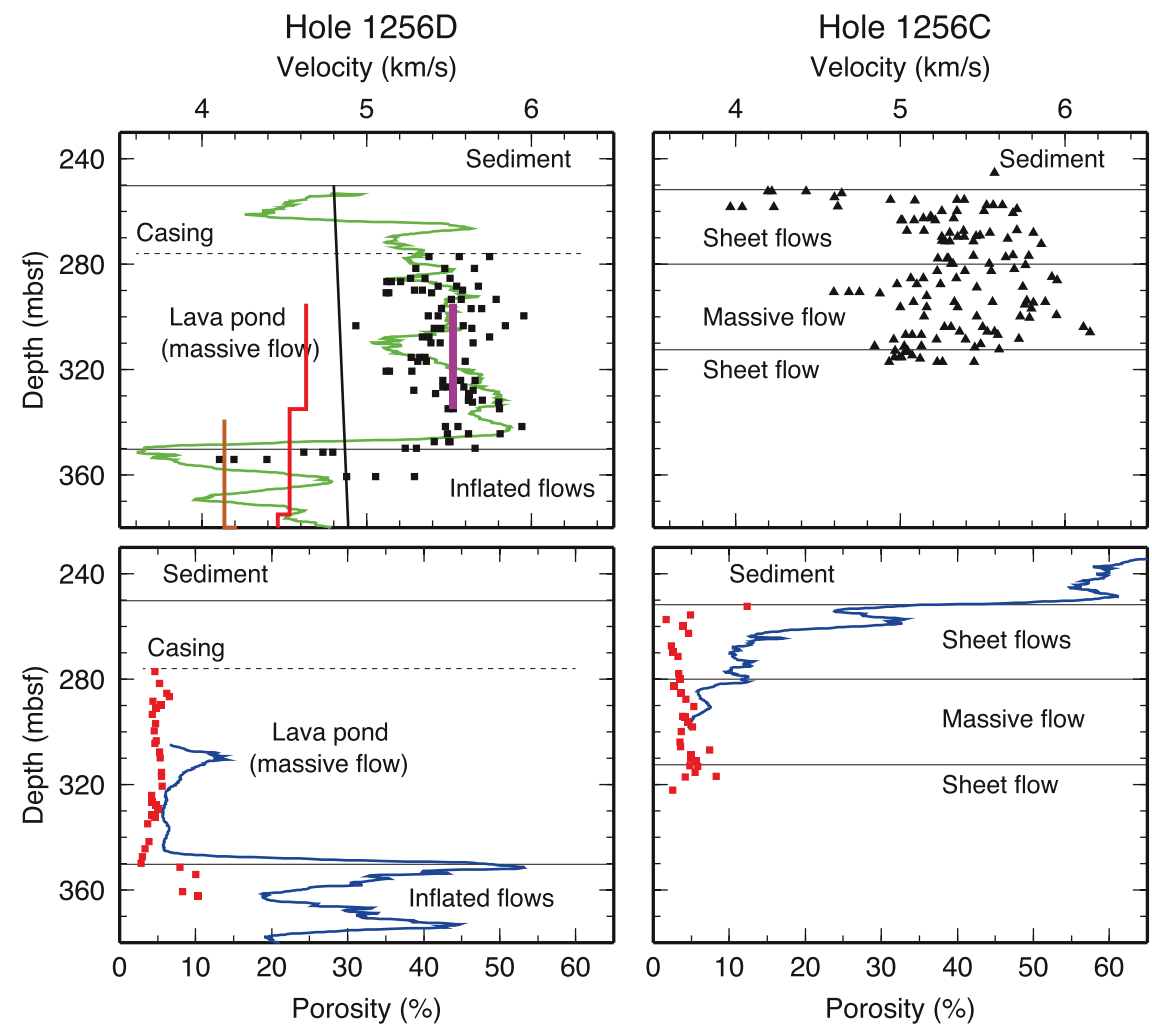

Figure 12. Velocity and porosity data indicate that both Holes $1256 \mathrm{C}$ and $1256 \mathrm{D}$ are capped by the Lava Pond unit comprising a massive flow underlying sheet flows. The massive flow thins from $>74 \mathrm{~m}$ at Hole $1256 \mathrm{D}$ to $32 \mathrm{~m}$ at Hole 1256C [Shipboard Scientific Party, 2003b]. Smoothed sonic velocity in Hole 1256D (green line) decreases to $4.2-4.8 \mathrm{~km} / \mathrm{s}$ within the uppermost $15 \mathrm{~m}$, consistent with a sheet flow unit that was bypassed during the casing operations. Black squares are velocities measured on minicubes from massive flows, and black triangles are undifferentiated velocities measured on minicubes from Hole 1256C. The black line is the refraction velocity profile, red line is the Leg 206 VSP profile, and the orange line is the Expedition 312 VSP profile. The magenta line shows the unsmoothed velocity between the uppermost two Leg 206 VSP seismometer clamping stations. Blue lines show smoothed porosity logs, and red squares are porosity values measured on minicubes.

type of flow over tens to hundreds of meters around the borehole. There is good agreement in the uppermost section of the unit, where velocity decreases from $5.5 \mathrm{~km} / \mathrm{s}$ above $350 \mathrm{mbsf}$ to $4.0-4.4 \mathrm{~km} / \mathrm{s}$ at $350-400 \mathrm{mbsf}$. This interval includes a sheet flow, the only pillow flows detected with certainty at Hole $1256 \mathrm{D}$, and a thin massive flow (Figure 13). Porosity from the neutron porosity sonde and porosity computed from the resistivity log are generally high. High porosity probably results from gaps and cracks that occurred during emplacement and cooling of the lava, tectonic fractures, and, later, to incomplete filling by precipitation of low-temperature/low-velocity hydrothermal minerals [Wilkens et al., 1991]. Deeper in the unit (400-534 mbsf), however, velocities from the sonic log and laboratory measurements increase by $\sim 1 \mathrm{~km} / \mathrm{s}$ in massive flow units, whereas velocities from both VSPs remain $>1 \mathrm{~km} / \mathrm{s}$ slower. The sonic log is unlikely to include errors great enough to explain the difference with the VSP results because sonic velocities are consistent with the laboratory measurements. The velocity difference is probably not due to errors in VSP velocities because they are well constrained by traveltimes (Figure 3). Low seismic velocities may be caused by widely spaced fractures that are unsampled by the borehole. However, fissures and faults commonly observed at fast spreading axes [e.g., Renard et al., 1985; Auzende et al., 1996] are generally nearvertical and parallel to the particle motion of the VSP compressional wave, so they are unlikely to slow propagation. Moreover, the discrepancy covers only a $\sim 100 \mathrm{~m}$ depth interval and is buried beneath $50-60 \mathrm{~m}$ of sheet flows, which is inconsistent with vertical tectonic fracturing. Last, the refraction velocity profile, which is determined from horizontally propagating seismic waves and is, thus, most sus- 

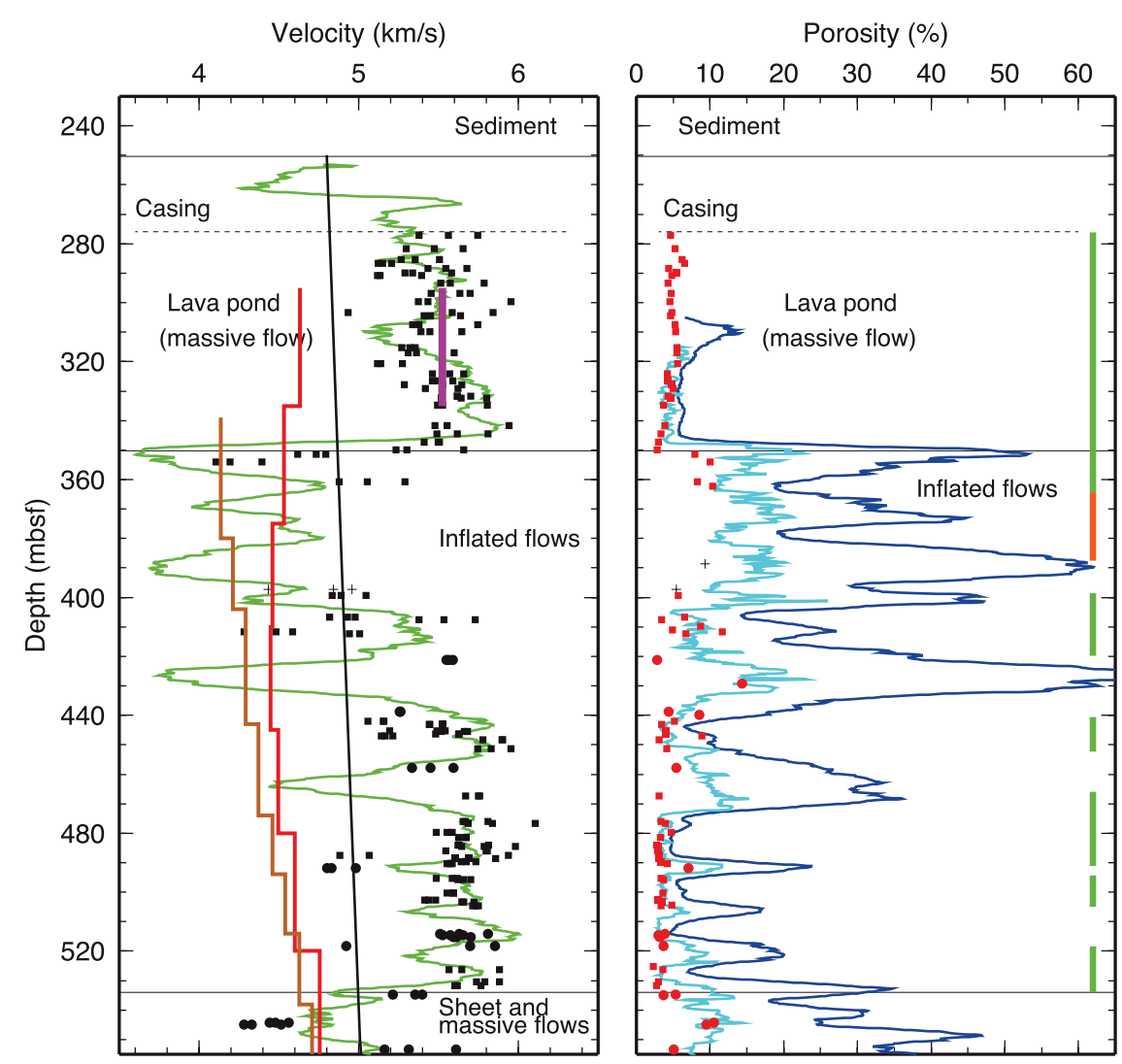

Figure 13. Velocities from the two VSPs agree with other measurements in the upper $50 \mathrm{~m}$ of the Inflated Flow unit but are generally $0.5-1.0 \mathrm{~km} / \mathrm{s}$ lower than other measurements below $400 \mathrm{mbsf}$. Low velocities in the upper portion of the unit are due to high porosity sheet and pillow layers, whereas high velocities in borehole measures are due to low-porosity massive layers. Black squares are velocities measured on minicubes from massive flows, circles are sheet flows, and crosses are breccias. The green line is the smooth sonic log, black line is the refraction velocity profile, red line is the Leg 206 VSP profile, and the orange line is the Expedition 312 VSP profile. The magenta line shows the unsmoothed velocity between the uppermost two Leg 206 VSP seismometer clamping stations. The dark blue line shows the smoothed neutron APS porosity log, light blue line shows porosity computed from resistivity, and red symbols are porosity values measured on minicubes. On the right side, green vertical bars indicate intervals of massive flows, and orange bars indicate a pillow layer. Intervals without a bar comprise breccias and sheets flows.

ceptible to slowing by vertical fractures, is greater than the VSP velocities in this interval.

[28] We suggest that the discrepancies are related to the type and distribution of flows. Figure 13 shows that the sonic log fluctuates between high velocities in low-porosity/massive flow intervals and low velocities in relatively high-porosity/sheet flow intervals. The few disagreements from this pattern are probably due to inaccurate lithologic interpretations for depth intervals based on incomplete core recovery. The discrepancy between VSP velocity and borehole measurements is likely due simply to lateral change in the relative proportion of massive and sheet flows. At the borehole, massive flows are common in the 400-530 mbsf interval, so porosity is low and velocity from the sonic $\log$ and minicores is generally high (5-
$5.6 \mathrm{~km} / \mathrm{s}$; Figure 13). VSP velocities, however, are influenced by rocks and structure occurring within the Freznel Zone, an area with a radius of several hundred meters. Low VSP velocity indicates that a large portion of this region away from the borehole comprises high-porosity sheet flow lavas rather than the massive flows encountered by the borehole.

[29] One hypothesis to explain this feature is that local topography evolved during the emplacement of the Inflated Flow Unit. An individual topographic obstruction with relief of $80-100 \mathrm{~m}$ or a composite structure of smaller relief could explain an abrupt lateral change in flow type. The hypothetical barrier could separate thicker, more massive flows drilled at Hole 1256D from thinner, more porous sheet flows that were erupted from a 

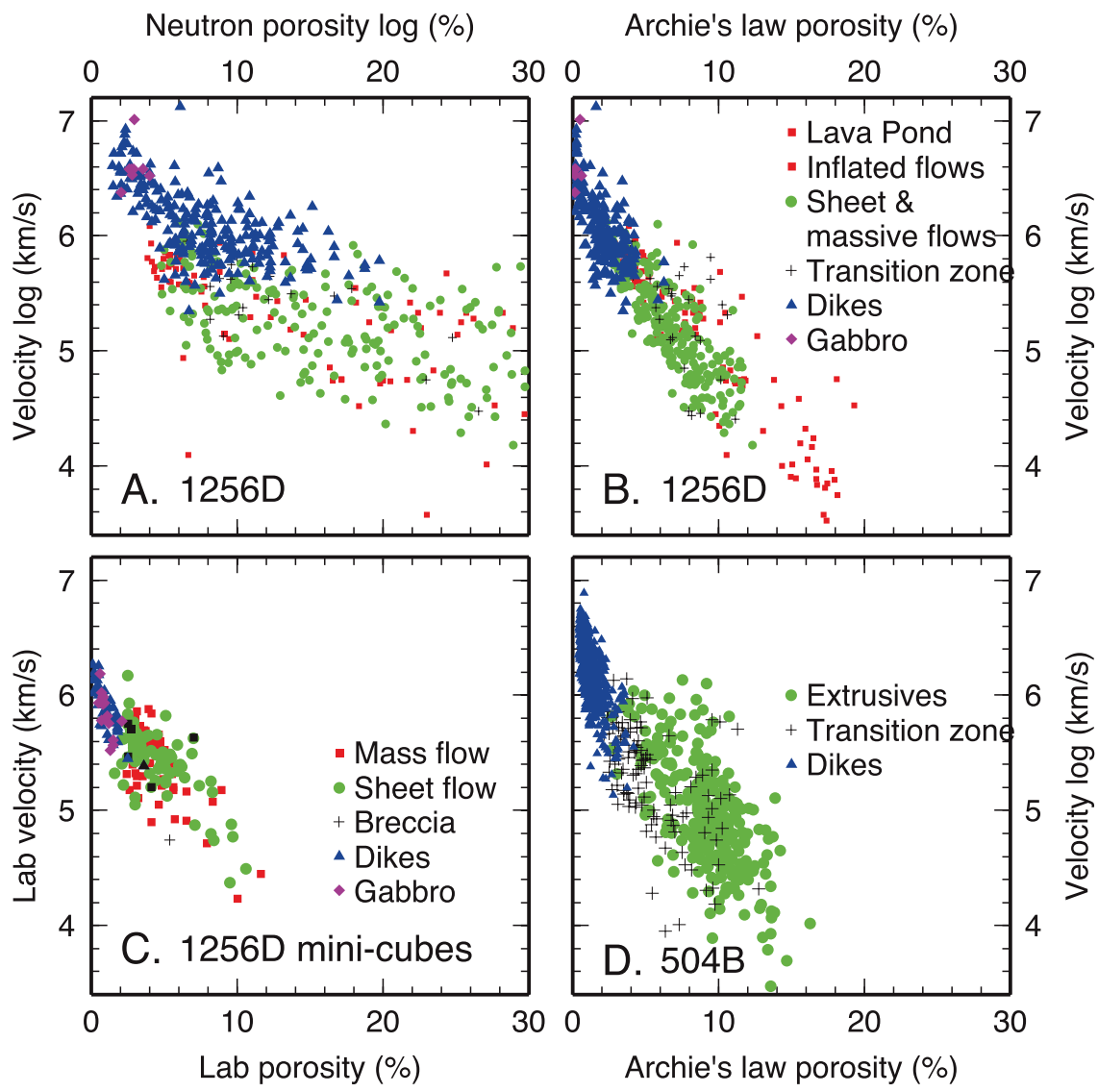

Figure 14. (a) In Hole 1256D the poor correlation between the APS porosity log and the sonic velocity log is likely due to errors in APS porosity (some values are $>100 \%$ ). (b) The correlation is much improved when porosity is computed from the resistivity log using Archie's law. (c) The correlation is equally good for minicubes, but pressurerelease cracking of gabbros and the deepest dike samples shifts these samples to higher porosity and lower velocities. (d) Using the sonic log and porosity computed from resistivity, the velocity-porosity relationship at Hole 504B is very similar to that at Hole 1256D shown in Figure 14b, although velocities above 6.8 are not reached. This resemblance reinforces our interpretation that porosity is the key factor controlling upper crustal velocity. The unsmoothed logs were averaged in $2 \mathrm{~m}$ nonoverlapping bins. Plots of $\log$ results in Figures 14a, 14b, and $14 \mathrm{~d}$ are colored according to igneous stratigraphy (depth), whereas the minicube samples in Figure $14 \mathrm{c}$ are colored according to rock type.

different source at a later time. There is evidence for such topography from ridge crest studies. Multibeam bathymetric mapping and near-bottom surveys on superfast and fast spreading centers reveal a wide range of topographic structures including axial collapse structures with relief of up to $25 \mathrm{~m}$ and cross-axis widths of hundreds of meters [Renard et al., 1985; White et al., 2000; Engels et al., 2003], long linear axial troughs with relief of 30-100 m and widths of 500-2000 m [Fornari et al., 1998; Lagabrielle and Cormier, 1999], and inward facing fault scarps of $\sim 40 \mathrm{~m}$ that appear 1-4 km off axis [Carbotte and Macdonald, 1994; Bohnenstiehl and Carbotte, 2001]. Alternatively, the vertical change in lithology may represent a change in relative strength of two adjacent vents tapping a single chamber but erupting differ- ent flow types that were active over a similar time period. Unfortunately, our data do not constrain the exact relief, lateral dimension, or azimuth of the volcanic structures near Site 1256, but future seismic investigations could be carefully designed to map and identify the nature of seismic velocity divisions within the Inflated Flow Unit. Our data, however, do allow us to conclude that thickness variations of over a hundred meters occur in the high-porosity/low-velocity layer of uppermost crust over lateral distance of less than few hundred meters.

\subsection{Porosity Controls on Velocity Variations}

[30] Velocity in seismic layer 2 is characterized by lateral variability and a downward increase with 


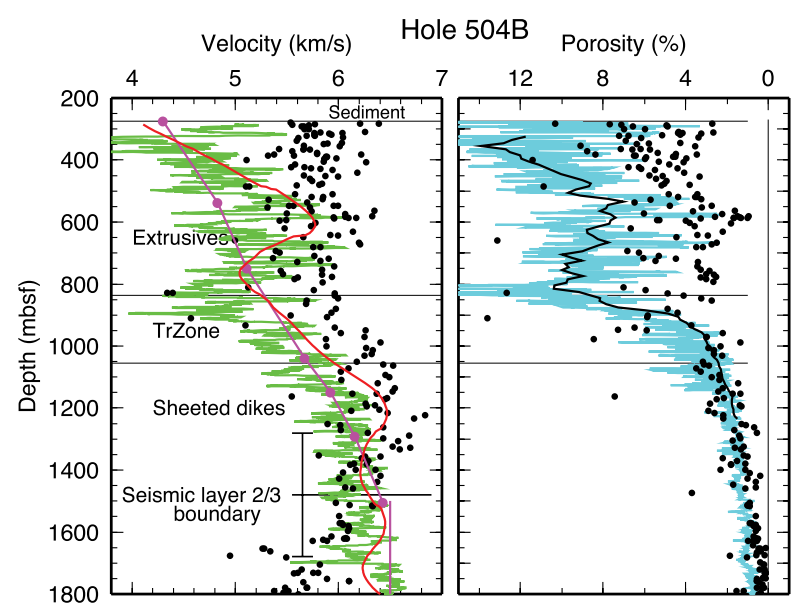

Figure 15. At Hole 504B, laboratory velocities (black circles) exceed or are similar to sonic log velocities (green; left) down to $1600 \mathrm{mbsf}$, which is within the error bounds for the seismic layer $2 / 3$ boundary [Detrick et al., 1994] and similar to the depth that the vertical gradient in porosity (right) drops to zero. Magenta lines are seismic velocities from Little and Stephen [1985] and Collins et al. [1995]. Red line shows VSP velocities from Swift et al. [1998a]. Light blue line is porosity computed from resistivity [Pezard et al., 1996] and black circles are porosity measured in the shipboard laboratory.

gradients of $1-2 \mathrm{~km} / \mathrm{s}$ per $\mathrm{km}$. These characteristics have been attributed to variations in the amount and shape of porosity [Spudich and Orcutt, 1980; Salisbury et al., 1985; Wilkens et al., 1991]. We test this hypothesis by examining the degree of covariation downhole in porosity and velocity. A close relationship is apparent by simple visual inspection of physical properties measurements made in the borehole by wireline logs. Smoothed sonic, neutron porosity, and resistivity logs correlate well with one another on both the scale of individual flow units $(5-30 \mathrm{~m})$ and thicker sequences (50-250 m) [Expedition 309/312 Scientists, 2006, Figure F342]. To confirm these apparent correlations, we averaged the unsmoothed logs in $2 \mathrm{~m}$ thick nonoverlapping bins. Figure 14a show a fair correlation between the neutron porosity and sonic logs obtained in the dikes and gabbros below 1060 mbsf. At shallower depths, however, porosity explains little of the variation in velocity. It is likely that the neutron porosity measurement is affected by the amount and mineralogy of alteration deposits as well as by porosity [e.g., Broglia and Ellis, 1990]. The measurement may also be more affected by changes in borehole diameter than the sonic log measurement of velocity. An alternative estimate of porosity can be computed from the resistivity log by making assumptions about the nature of the electrical properties of the material filling voids in the rock (Figures 8 and 13) [Becker et al., 1982; Pezard, 1990]. Figure 14c shows that the amount of porosity computed from resistivity explains most of the variation in sonic $\log$ velocity. The relationship does not change across lithologic boundaries and includes coarsegrained gabbros, microcrystalline dike basalts, and erupted lavas. This result indicates that velocity variations in the borehole walls, with all the contributions from cracks, veins, and poorly sampled rocks, can be attributed to vertical changes in porosity. The relationship breaks down at porosity values $<1 \%$ (Figure $14 \mathrm{c}$ ), where velocity values range over $6.1-7.0 \mathrm{~km} / \mathrm{s}$. Porosity reaches such low values near 1275 mbsf. Below this depth, porosity may be closed sufficiently that variations in alteration minerals play a more important role in determining velocity. Microfracturing, described above, may also contribute. We conclude that the amount of porosity, and not the shape of pores, is sufficient to explain the variations in velocity under in situ conditions in the upper $\sim 1 \mathrm{~km}$ of basement at Site 1256.

[31] Figure $14 \mathrm{~d}$ shows a similar relationship is found at Hole 504B. Here there is more scatter in velocity at porosity values of $6-12 \%$ in the extrusive lavas. This may be due to systematic differences in the way pores are filled with clay minerals as suggested by Wilkens and Salisbury [1996]. The agreement indicates that the close relationship of velocity to porosity is not peculiar to Hole 1256D.

[32] The correlation between porosity and velocity extends to the centimeter length scale. Figure 14b shows that minicube porosity accounts for most of the variation in minicube velocity. The relationship is tightest at porosities $<3 \%$ in the dikes and gabbros. The disagreement between the fits to the $\log$ data in Figures 14c and the minicube data in Figure $14 \mathrm{~b}$ is due in part to the decrease in velocity caused by microfracturing of diabases and gabbros minicubes recovered below 1275-1325 mbsf and to the bias at depths $<800 \mathrm{mbsf}$ for minicube samples to be taken almost entirely from unfractured core rock in massive flows. These samples are generally chosen from the more competent, least cracked samples of rock recovered because smooth faces and edges are required to get velocity measurements with the PWS3 transducers and event picking software. So, unrecovered rocks are missing, and rocks containing veins and cracks are underrepresented. This bias is clearly seen in 


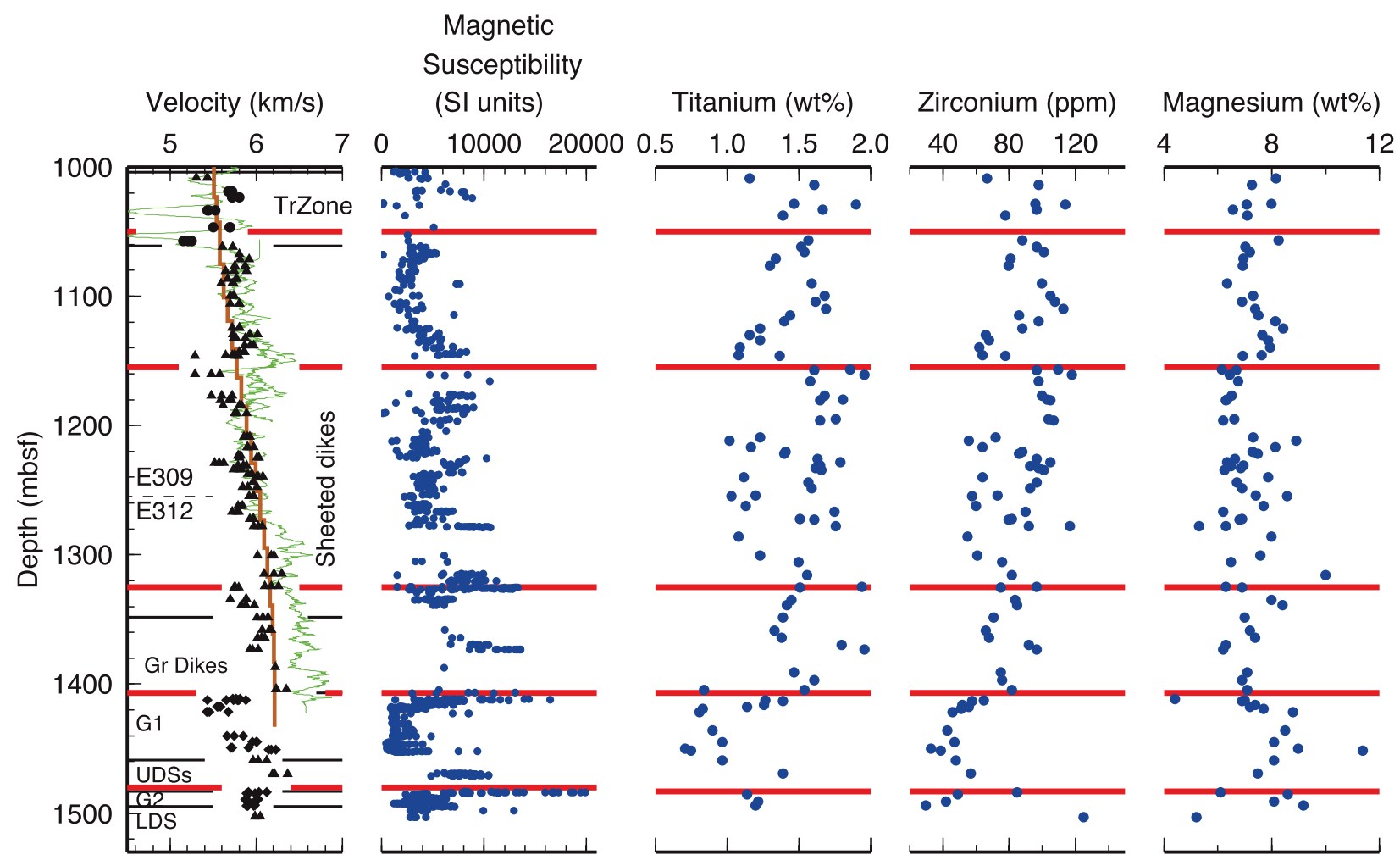

Figure 16. The boundaries of dike clusters (horizontal red lines) defined on the basis of velocity (left, see also Figure 8) coincide with changes in other physical properties (magnetic susceptibility, see also Figure 8) and with small offsets in the depth trend of the incompatible elements titanium and zirconium and with the compatible element magnesium.

Figure 4 in the clustering of measurements with velocities of $5.2-5.8 \mathrm{~km} / \mathrm{s}$ at depths of $250-$ 750 mbsf. The reasonably tight fit for measurements made on minicubes (Figure 14b) indicates that the variance in velocity between core samples is explained by variation in porosity.

[33] We extrapolate these correlations between porosity and velocity to the seismic length scale. We do not have porosity measurements over scales of tens of meters such as those obtained by Becker et al. [1982] at Hole 504B using widely spaced electrical nodes. But the seismic velocities obtained from both the VSP and the seismic refraction experiments agree within $\pm 0.3 \mathrm{~km} / \mathrm{s}$ to the range of minicube values at most depths (Figure 5). The exceptions noted above include low VSP velocities in the lower portion of the Inflated Flow unit ascribed to lateral variations in geology and the low minicube velocities below 1275-1325 mbsf ascribed to microfracturing from pressure release. These simple comparisons demonstrate a remarkable consistency over a wide range of length scales. The correspondence between velocities determined at all length scales supports the conjecture that porosity is the primary factor in determining ve- locity in the uppermost $1 \mathrm{~km}$ of superfast spreading crust.

[34] The porosity-velocity relationship in the upper $1250 \mathrm{~m}$ of basement at Hole 1256D indicates that the overall gradients in seismic velocity in upper ocean crust may be accounted for by changes in porosity. In particular, the change in gradient at the seismic layer $2 / 3$ boundary may be the result of closure of cracks on scales less than $1 \mathrm{~cm}$. The present data from Hole 1256D are inadequate to fully test this conjecture because drilling stopped short of the refraction boundary at $\sim 1500$ mbsf (Figure 4). Measured porosity approaches zero at 1275-1325 mbsf (Figures 6 and 8), which lies $250 \mathrm{~m}$ above the refraction layer $2 / 3$ boundary ( 1500 mbsf in Figure 5). Some of this difference may be due to errors in the boundary depth arising from using $10 \mathrm{~Hz}$ seismic energy with a $650 \mathrm{~m}$ wavelength. This depth interval may also include closure of residual unmeasured porosity. Porosity may explain the change in velocity gradient at Hole 504B where the hole clearly penetrated well below the layer 2/3 boundary [Salisbury et al., 1985]. In Hole 504B (Figure 15), porosity computed from resistivity increases down to 1500 mbsf [Pezard 
et al., 1996]. Lab porosity decreases down to 1650 mbsf. These changes occur at depths that fall within the error bars on the seismic layer $2 / 3$ boundary defined by Detrick et al. [1994] and coincide with the decrease in laboratory velocity below sonic log velocities (Figure 15). Thus, the data from the two deepest holes in upper ocean crust suggest that porosity variability on scales $<1 \mathrm{~cm}$ may account for seismic velocity variations. Observations in drill holes, ophiolites, fracture zones, and rift zones indicate that with time, primary porosity is closed by filling of fractures by sediment, breccia and talus, collapse of voids and compression of microcracks under overburden pressure, and deposition of minerals by hydrothermal fluids [Wilkens et al., 1991]. Large-scale fractures and fissures are not required to explain the velocity profiles at Hole 1256D. The contribution from mineralogical changes to velocity is unclear at this stage in analysis of 1256D rocks. Further work will address the relative contribution of original porosity differences, metamorphism, and mineralization on porosity.

\subsection{Dike Clusters}

[35] In the sheeted dikes at Hole 1256D, we find that small but significant changes in velocity and porosity occur at changes in boundaries between lithologic units and suggest that these changes are a general feature of dike stratigraphy. Below the Transition Zone, the borehole penetrated chilled margins interpreted as at least nine igneous contacts between dikes [Expedition 309/312 Scientists, 2006]. The borehole dips only $4-5^{\circ}$ at these depths, whereas dips of the dikes, estimated from igneous contacts and chilled margins, have a mean of $70^{\circ}$ and range from $41^{\circ}$ to $88^{\circ}$ [Tartarotti et al., 2006]. Above the transition to the plutonic section, however, the laboratory velocity sequence is broken into at least three segments at $1155 \mathrm{mbsf}$ and $1325 \mathrm{mbsf}$ by abrupt velocity decreases of $0.5-$ $0.6 \mathrm{~km} / \mathrm{s}$ (red horizontal lines in Figures 7 and 8). These velocity changes are defined by several samples and exceed variability due to measurement error. The transition occurs across $<1 \mathrm{~m}$ at $1325 \mathrm{mbsf}$. Sonic log velocity decreases by $>0.5 \mathrm{~km} / \mathrm{s}$ at $1155 \mathrm{mbsf}$ but changes little at $1325 \mathrm{mbsf}$. These segment boundaries occur at igneous contacts interpreted as dike boundaries based on igneous petrologic description and appear to define clusters of dikes. Within each cluster laboratory velocity increases downhole at gradients of $3.2-6.5 \mathrm{~km} / \mathrm{s}$ per $\mathrm{km}$. There are coincident changes in porosity and thermal con- ductivity but not in density (Figure 6). Magnetic susceptibility peaks near cluster boundaries at 1155 and 1325 mbsf and at the top of each gabbro unit (Figure 8). There are coincident changes of magnitude, gradient, and variability in both the resistivity $\log$ and porosity computed from resistivity (Figure 8). Figures 9 and 16 show changes in mineralogy and chemistry, as well. Mesostasis disappears below 1325 mbsf. In the dike cluster between $1325 \mathrm{mbsf}$ and $1407 \mathrm{mbsf}$, clinopyroxene $(>30 \%)$ and magnetite $(5-10 \%)$ and actinolite (10$45 \%$ ) are high. Small changes in the amounts of $\mathrm{Mg}$ and the incompatible elements $\mathrm{Ti}$ and $\mathrm{Zr}$ correlate with the boundaries defined by physical properties. Zuleger et al. [1995] found similar chemical variations in the dikes at Hole 504B in crust formed at intermediate spreading rates. Thus, trends in physical properties and the abundance of minerals and chemical components define segments of $80-150 \mathrm{~m}$ depth range, which we interpret as clusters of dikes.

[36] The origin of the clusters is unclear this early in the analysis of Hole 1256D. In particular, it is uncertain whether gradational changes in velocity, resistivity, and magnetic susceptibility within the clusters are original emplacement characteristics or effects created later during alteration by hydrothermal processes. From the chemical changes, it could be inferred that the clusters are primary igneous features representing lava injections at different times from an evolving melt. Alternatively, the abrupt drop in velocity at cluster boundaries may be due to mechanical or thermal stress imposed by later dikes. Karson et al. [2002] and Karson [2002] describe packages or "panels" of dikes exposed in Hess Deep. Panels are separated by fractured deformation zones or faults. It is possible that these zones either restricted or enhanced fluid circulation leading to lateral changes in the nature or degree of alteration affecting porosity and, thus, velocity. Magnetite is a prominent alteration mineral whose concentration may be related to vertical variations in magnetic susceptibility. We infer that structures with length scales greater than individual dikes $(0.5-2 \mathrm{~m})$ influenced postemplacement hydrothermal circulation through the sheeted dikes but recognize that additional studies may revise this interpretation.

\section{Conclusions}

[37] 1. Microfracturing affects rocks recovered from deeper than $1275 \mathrm{mbsf}$ (1 km subbasement) more than rocks recovered from above 1275 mbsf. 
[38] 2. At basement depths $<280 \mathrm{~m}$, the lateral and vertical distribution of flow types controls porosity and, thus, the seismic velocity of the basement surface, a key parameter determining the vertical velocity gradient in seismic layer 2 .

[39] 3. Variations in porosity control velocity in the upper $1 \mathrm{~km}$ of ocean crust. Closure of porosity may explain the transition between seismic layers 2 and 3.

[40] 4. Physical, mineralogical, and chemical properties define primary igneous clusters of dikes with apparent thicknesses of 80-150 $\mathrm{m}$ that may have influenced subsequent alteration processes.

\section{Acknowledgments}

[41] We thank the science parties of ODP Leg 206 and IODP Expeditions 309 and 312 for many discussions and the contribution of shipboard mineralogy results used in this paper. We especially thank Doug Wilson for a careful review and for corrections that significantly improved the manuscript. Swift thanks R. Stephen, D. Lizarralde, W. L. Zhu, and M. Behn (all WHOI) for sharing ideas and suggestions. J. Inwood (Univ. Leicester) kindly provided postcruise checks of our laboratory velocity measurements. G. Guerin (LDEO/ BRG) re-processed the Expedition 312 compressional sonic log. A. Harding (SIO) very kindly provided the refraction velocity model for Site 1256 . We processed seismograms using software written by W. Wilcock (UW) and D. Lizarralde (WHOI) and used GMT (Wessel and Smith) to plot most figures. The success of the VSP was due in large part to considerable effort by the captain and crew of the $\mathrm{D} / \mathrm{V}$ JOIDES Resolution, shipboard technical staff from IODP/ TAMU, and the Schlumberger logging engineers. This research used samples and/or data provided by the Integrated Ocean Drilling Program (IODP). Funding for this research was provided by Joint Oceanographic Institutions (JOI) Task Order T312A26 and NSF grant OCE-0424633.

\section{References}

Alt, J. C., et al. (1996), Hydrothermal alteration of a section of upper oceanic crust in the eastern Equatorial Pacific: A synthesis of results from Site 504 (DSDP Legs 69, 70, and 83, and ODP Legs 111, 137, 140, and 148), Proc. Ocean Drill. Program Sci. Results, 148, 417-434.

Auzende, J.-M., et al. (1996), Recent tectonic, magmatic, and hydrothermal activity on the East Pacific Rise between $17^{\circ} \mathrm{S}$ and $19^{\circ} \mathrm{S}$; submersible observations, J. Geophys. Res., 101, 17,995-18,010, doi:10.1029/96JB01209.

Becker, K., et al. (1982), In situ electrical resistivity and bulk porosity of the oceanic crust Costa Rica Rift, Nature, 300, 594-598, doi:10.1038/300594a0.

Becker, K., et al. (1998), Proceedings of the Ocean Drilling Program, Initial Reports, vol. 174B, Ocean Drill. Program, College Station, Tex.

Blum, P. (1997), Physical properties handbook: A guide to the shipboard measurement of physical properties of deep-sea cores, Tech. Note 26, Ocean Drill. Program, College Station,
Tex. (Available at http://www-odp.tamu.edu/publications/ tnotes/tn26/INDEX.HTM)

Bohnenstiehl, D. R., and S. M. Carbotte (2001), Faulting patterns near $19^{\circ} 30^{\prime} \mathrm{S}$ on the East Pacific Rise: Fault formation and growth at a superfast spreading center, Geochem. Geophys. Geosyst., 2(9), 1056, doi:10.1029/2001GC000156.

Broglia, C., and D. Ellis (1990), Effect of alteration, formation absorption, and standoff on the response of the thermal neutron porosity log in gabbros and basalts: Examples from Deep Sea Drilling Project-Ocean Drilling Program sites, J. Geophys. Res., 95(B6), 9171-9188, doi:10.1029/ JB095iB06p09171.

Carbotte, S. M., and K. C. Macdonald (1994), The axial topographic high at intermediate and fast spreading ridges, Earth Planet. Sci. Lett., 128, 85-97, doi:10.1016/0012-821X(94)90137-6.

Carlson, R. L. (2004), Seismic properties of layer 2A at $11 \mathrm{Ma}$ Results of a vertical seismic profile at Ocean Drilling Program Site 1243, Geophys. Res. Lett., 31, L17601, doi:10.1029/2004GL020598.

Collins, J. A., R. S. Detrick, R. A. Stephen, G. M. Kent, and S. A. Swift (1995), Hole 504B seismic experiment; new constraints on the depth to the seismic layer 2/layer 3 boundary, Eos Trans. AGU, 76(46), Fall Meet. Suppl., F616.

Constable, S. C., R. L. Parker, and C. G. Constable (1987), Occam's inversion: A practical algorithm for generating smooth models from electromagnetic sounding data, Geophysics, 52, 289-300, doi:10.1190/1.1442303.

Detrick, R. S., J. Collins, R. Stephen, and S. Swift (1994), In situ evidence for the nature of the seismic layer $2 / 3$ boundary in oceanic crust, Nature, 370, 288-290, doi:10.1038/ $370288 \mathrm{a} 0$.

Detrick, R. S., D. R. Toomey, and J. A. Collins (1998), Threedimensional upper crustal heterogeneity and anisotropy around Hole 504B from seismic tomography, J. Geophys. Res., 103, 30,485-30,504, doi:10.1029/98JB02409.

Embley, R. W., J. E. Lupton, G. Massoth, T. Urabe, V. Tunnicliffe, D. A. Butterfield, T. Shibata, O. Okano, M. Kinoshita, and K. Fujioka (1998), Geologic, chemical, and biological evidence for Recent volcanism at 17.5 degrees S; East Pacific Rise, Earth Planet. Sci. Lett., 163, 131-147, doi:10.1016/S0012-821X (98)00181-2.

Engels, J. L., M. H. Edwards, D. J. Fornari, M. R. Perfit, and J. R. Cann (2003), A new model for submarine volcanic collapse formation, Geochem. Geophys. Geosyst., 4(9), 1077, doi:10.1029/2002GC000483.

Expedition 309/312 Scientists (2006), Site 1256, in Proceedings of Integrated Ocean Drilling Program, vol. 309/312, edited by D. A. H. Teagle et al., pp. 1-549, Integ. Ocean Drill. Program Manage. Int., Washington, D. C.

Fornari, D. J., R. M. Haymon, M. R. Perfit, T. K. P. Gregg, and M. H. Edwards (1998), Axial summit trough of the east Pacific rise 9 degrees-10 degrees N: Geological characteristics and evolution of the axial zone on fast spreading midocean ridges, J. Geophys. Res., 103, 9827-9855, doi:10.1029/98JB00028.

Hallenborg, E., A. J. Harding, G. M. Kent, and D. S. Wilson (2003), Seismic structure of 15 Ma oceanic crust formed at an ultrafast spreading East Pacific Rise: Evidence for kilometerscale fracturing from dipping reflectors, reflectors, $J$. Geophys. Res., 108(B11), 2532, doi:10.1029/2003JB002400.

Hardage, B. A. (1983), Vertical Seismic Profiling, Part A, Principles, Geophys. Press, London.

Helmberger, D. V., and G. B. Morris (1969), A traveltime and amplitude interpretation of a marine refraction profile: Primary waves, J. Geophys. Res., 74, 483-494, doi:10.1029/ JB074i002p00483. 
Houtz, R., and J. Ewing (1976), Upper crustal structure as a function of plate age, J. Geophys. Res., 81, 2490-2498, doi:10.1029/JB081i014p02490.

Hyndman, R. D. (1979), Poisson's ratio in the oceanic crust - a review, Tectonophysics, 59, 321-333, doi:10.1016/00401951(79)90053-2.

Hyndman, R. D., and M. J. Drury (1976), The physical properties of oceanic basement rocks from deep drilling on the Mid-Atlantic Ridge, J. Geophys. Res., 81, 4042-4052, doi:10.1029/JB081i023p04042.

Karson, J. A. (2002), Geologic structure of uppermost oceanic crust created at fast- to intermediate-rate spreading centers, Annu. Rev. Earth Planet. Sci., 30, 347-384, doi:10.1146/ annurev.earth.30.091201.141132.

Karson, J. A., E. M. Klein, S. D. Hurst, C. E. Lee, P. A. Rivizzigno, D. Curewitz, A. R. Morris, and Hess Deep '99 Scientific Party (2002), Structure of uppermost fast-spread oceanic crust exposed at the Hess Deep Rift: Implications for sub-axial processes at the East Pacific Rise, Geochem. Geophys. Geosyst., 3(1), 1002, doi:10.1029/2001GC000155.

Lagabrielle, Y., and M. H. Cormier (1999), Formation of large summit troughs along the East Pacific Rise as collapse calderas: An evolutionary model, J. Geophys. Res., 104(B6), 12,971-12,988, doi:10.1029/1999JB900015.

Little, S. A., and R. A. Stephen (1985), Costa Rica Rift borehole seismic experiment, Deep Sea Drilling Project Hole 504B, Leg 92, Initial Rep. Deep Sea Drill. Proj., 83, $517-528$

Lizarralde, D., and S. Swift (1999), Smooth inversion of VSP traveltime data, Geophysics, 64, 659-661, doi:10.1190/ 1.1444574

Macdonald, K. C., R. Haymon, and A. Shor (1989), A 220 km2 recently erupted lava field on the East Pacific Rise near lat $8^{\circ} \mathrm{S}$, Geology, 17, 212-216, doi:10.1130/0091-7613(1989) 017<0212:AKRELF $>2.3 . \mathrm{CO} ; 2$.

Moos, D., and P. A. Pezard (1996), Relationships between strengths and physical properties of samples recovering during legs 137, 140, and 148 from Hole 504B, Proc. Ocean Drill. Program Sci. Results, 148, 401-407.

Morrow, C., D. Lockner, S. Hickman, M. Rusanov, and T. Roeckel (1994), Effects of lithology and depth on the permeability of core samples from the Kola and KTB drillholes, J. Geophys. Res., 99, 7263-7274, doi:10.1029/93JB03458.

Orcutt, J. A., B. L. N. Kennett, and L. M. Dorman (1976), Structure of the East Pacific Rise from an ocean bottom seismometer array, Geophys. J. R. Astron. Soc., 45, 305320.

Pezard, P. A. (1990), Electrical properties of mid-ocean ridge basalt and implications for the structure of the upper ocean crust in Hole 504B, J. Geophys. Res., 95, 9237-9264, doi:10.1029/JB095iB06p09237.

Pezard, P. A., and R. N. Anderson (1989), Morphology and alteration of the upper oceanic crust from in-situ electrical experiments in DSDP/ODP Hole 504B, Proc. Ocean Drill. Program Sci. Results, 111, 133-146.

Pezard, P. A., K. Becker, A. Revil, M. Ayadi, and P. K. Harvey (1996), Fractures, porosity, and stress in the dolerites of Hole 504B, Costa Rica Rift, Proc. Ocean Drill. Program Sci. Results, 148, 317-329.

Raitt, R. W. (1963), The crustal rocks, in The Sea, Ideas and Observations on Progress in the Study of the Seas, vol. 3, The Earth Beneath the Sea, edited by M. N. Hill, pp. 85102, Wiley Interscience, New York.

Renard, V., R. Hekinian, J. Francheteau, R. D. Ballard, and H. Backer (1985), Submersible observations at the axis of the ultra-fast-spreading East Pacific Rise ( $17^{\prime \prime} 30^{\prime}$ to $\left.21^{\circ} 30^{\prime} \mathrm{S}\right)$,
Earth Planet. Sci. Lett., 75, 339-353, doi:10.1016/0012821X(85)90178-5.

Salisbury, M. H., N. I. Christensen, K. Becker, and D. Moos (1985), The velocity structure of layer 2 at Deep Sea Drilling Project Site 504 from logging and laboratory experiments, Initial Rep. Deep Sea Drill. Proj., 83, 529-539.

Sheriff, R. E., and L. P. Geldart (1982), Exploration Seismology, vol. 1, History, Theory and Data Acquisition, Cambridge Univ. Press, New York.

Shipboard Scientific Party (1988), Site 504, Proc. Ocean Drill. Program Initial Rep., 111, 32-251.

Shipboard Scientific Party (2003a), Leg 206 Summary, Proc. Ocean Drill. Program Initial Rep., 206, 1-117.

Shipboard Scientific Party (2003b), Site 1256, Proc. Ocean Drill. Program Initial Rep., 206, 1-396.

Shipboard Scientific Party (2003c), Site 1243, Proc. Ocean Drill. Program Initial Rep., 203, 1-85.

Sinton, J., E. Bergmanis, K. Rubin, R. Batiza, T. K. P. Gregg, K. Gronvold, K. C. Macdonald, and S. M. White (2002), Volcanic eruptions on mid-ocean ridges; new evidence from the superfast spreading East Pacific Rise, $17^{\circ}-19^{\circ} \mathrm{S}, \mathrm{J}$. Geophys. Res., 107(B6), 2115, doi:10.1029/2000JB000090.

Spudich, P., and J. A. Orcutt (1980), Petrology and porosity of an oceanic crust site: Results from waveform modeling of seismic refraction data, J. Geophys. Res., 85, 1409-1433.

Stephen, R. A. (1988), Lateral heterogeneity in the upper oceanic crust at Deep Sea Drilling Project Site 504, J. Geophys. Res., 93, 6571-6584.

Swift, S. A., H. Hoskins, and R. A. Stephen (1996), Vertical seismic profile into upper ocean crust in Hole 504B, Proc. Ocean Drill. Program Sci. Results, 148, 339-347.

Swift, S. A., D. Lizarralde, R. A. Stephen, and H. Hoskins (1998a), Velocity structure in upper ocean crust at Hole 504B from vertical seismic profiles, J. Geophys. Res., 103, 15,361-15,376, doi:10.1029/98JB00766.

Swift, S. A., G. M. Kent, R. S. Detrick, J. A. Collins, and R. A. Stephen (1998b), Oceanic basement structure, sediment thickness, and heat flow near Hole 504B, J. Geophys. Res., 103, 15,377-15,391, doi:10.1029/98JB00698.

Tartarotti, P., L. Crispini, and the IODP Exp 309 Shipboard Scientific Party (2006), ODP-IODP Site 1256 (East Pacific Rise): An example of in-situ section of upper oceanic crust formed at a superfast spreading rate, Ofioliti, 31, 107-116.

Tikku, A. A., S. A. Swift, D. A. Lockner, and M. K. Reichow (2006), Correlation of deep crustal seismic velocity anomalies and intrusive units in the vicinity of the sheeted-dikegabbro boundary at IODP Site 1256D, Eos Trans. $A G U$, 87(52), Fall Meet. Suppl., Abstract T53B-1608.

White, R. S. (1979), Oceanic upper crustal structure from variable angle seismic reflection-refraction profiles, J. Geophys. Res., 57, 683-726.

White, S. M., K. C. Macdonald, and R. M. Haymon (2000), Basaltic lava domes, lava lakes, and volcanic segmentation on the southern East Pacific Rise, J. Geophys. Res., 105, 23,519-23,536, doi:10.1029/2000JB900248.

Whitmarsh, R. B. (1978), Seismic refraction studies of the upper igneous crust in the North Atlantic and porosity estimates for Layer 2, Earth Planet. Sci. Lett., 37, 451-464, doi:10.1016/0012-821X(78)90061-4.

Wilkens, R. H., and M. H. Salisbury (1996), Microstructure and physical properties of samples from Hole 896A, Proc. Ocean Drill. Program Sci. Results, 148, 365-374.

Wilkens, R. H., G. J. Fryer, and J. Karsten (1991), Evolution of porosity and seismic structure of upper oceanic crust; importance of aspect ratios, J. Geophys. Res., 96, 17,981-17,995, doi:10.1029/91JB01454. 
Wilson, D. S. (1996), Fastest known spreading on the Miocene Cocos-Pacific plate boundary, Geophys. Res. Lett., 23, 3003-3006, doi:10.1029/96GL02893.

Wilson, D. S., et al. (2003a), Proceedings of the Ocean Drilling Program, Initial Reports, vol. 206, Ocean Drill. Program, College Station, Tex.

Wilson, D. S., E. Hallenborg, A. J. Harding, and G. M. Kent (2003b), Site survey results from Cruise EW9903, Proc. Ocean Drill. Program Initial Rep., 206, 1-49.
Wilson, D. S., et al. (2006), Drilling to gabbro in intact ocean crust, Science, 312(5776), 1016-1020, doi:10.1126/science. 1126090.

Wright, D. J., R. M. Haymon, S. M. White, and K. C. Macdonald (2002), Crustal fissuring on the crest of the southern East Pacific Rise at $17^{\circ} 15^{\prime}-40^{\prime} \mathrm{S}$, J. Geophys. Res., 107(B5), 2104, doi:10.1029/2001JB000544.

Zuleger, E., J. C. Alt, and J. Erzinger (1995), Primary and secondary variation in major and trace element geochemistry of the lower sheeted dike complex: Hole 504B, Leg 140, Proc. Ocean Drill. Program Sci. Results, 137/170, 65-80. 